\title{
Characterizing elemental, equivalent black, and refractory black carbon aerosol particles: a review of techniques, their limitations and uncertainties
}

\author{
Daniel A. Lack • Hans Moosmüller • Gavin R. McMeeking • \\ Rajan K. Chakrabarty • Darrel Baumgardner
}

Received: 2 August 2013 / Revised: 18 September 2013 / Accepted: 25 September 2013 / Published online: 3 December 2013

(C) The Author(s) 2013. This article is published with open access at Springerlink.com

\begin{abstract}
Elemental-, equivalent black- and refractory blackcarbon are terms that have been defined in order to dissect the more general term, black carbon, into its component parts related to its specific chemical and optical properties and its impact on climate and health. Recent publications have attempted to clarify the meaning of these terms with respect to their environmental impact, particularly on climate. Here, we focus on the measurement aspects, reviewing the most commonly implemented techniques for the direct and indirect derivation of black carbon properties, their strengths, limitations, and uncertainties, and provide a non-exhaustive bibliography where the reader can find more detailed information. This review paper is designed as a guide for those wishing to learn about the current state of black carbon measurement instrumentation, how calibration is carried out, when one instrument may have the advantage over another, and where new techniques are needed to fill important knowledge gaps.
\end{abstract}

Keywords Aerosols $\cdot$ Particulates $\cdot$ Chemical sensors · Optical sensors $\cdot$ Thermal methods

Published in the special paper collection Analytical Chemistry Related to Climate Change and Environmental Sustainability with guest editors Richard J. C. Brown and Carlos A. Gonzalez.

\section{A. Lack}

NOAA Earth System Research Laboratory, 325 Broadway, Boulder, CO 80305-3337, USA

H. Moosmüller • R. K. Chakrabarty

Desert Research Institute, Reno, NV, USA

G. R. McMeeking $\cdot$ D. Baumgardner $(\bowtie)$

Droplet Measurement Technologies, 2545 Central Avenue,

Boulder, CO 80301, USA

e-mail: darrel.baumgardner@gmail.com

D. A. Lack

Cooperative Institute for Research in Environmental Sciences,

University of Colorado, Boulder, CO 80309, USA

\section{Introduction}

The title of this manuscript specifically avoids the use of the simplified term "black carbon (BC)" in order to emphasize that $\mathrm{BC}$ has been used for years as a catch-all term to describe a variety of types of carbonaceous particles. These types of particles are an important and ubiquitous component of the atmosphere that impact climate because of their direct interaction with solar radiation. Some fraction of them indirectly modify climate through their activation as cloud droplets or ice crystals whose size make them more effective dispersers of radiation than when they are aerosol particles [1, 2]. Their emissions from sources of combustion, man-made or through natural events, can modify the weather inadvertently by increasing the number of small water droplets while decreasing the production of rain or snow, an event that is still largely not understood yet generally accepted as an important factor in changing precipitation patterns [3, 4].

Only very recently, within the last 10 years, have researchers started identifying which types of aerosol particles have the largest impact on health. The general correlation between particle mass and mortality/morbidity has been well documented but more recent studies have established a causal link between carbonaceous particles and cardiovascular, respiratory, and neurological problems, although a great deal more research is needed to understand which properties of the particles are responsible for inciting physical disorders [5].

The need to quantify and document the properties of carbonaceous particles has led to the development and proliferation of a number of different instruments that measure these properties using a variety of techniques. Some of the older of these have been extensively evaluated, whereas the newer ones are still being studied to better understand their limitations and the uncertainties associated with their measurements. There are also numerous technical articles that describe the operating principles of these instruments as well as a number of studies comparing one technique against another. 
Given the increasing number of investigators in a broad range of scientific disciplines who are interested in the measurement of carbonaceous particle properties to support their research in climate change, air quality, glaciology, health, and in other topics where these type of particles have significant impact, it seemed timely to write a succinct review of the most commonly used instruments that measure these particle properties. This presentation is meant to be a guide to those who are new to this field of research and wish to learn the basic operating principles of the instruments, their uncertainties and limitations, and to find literature references where more detail may be unearthed.

\section{Definitions}

Carbonaceous particles have many different properties but we will focus here only on the properties of those particles that are produced from combustion of fossil fuels and biomass and their physical, optical, and chemical properties. Because of the confusion over the years concerning terminology, we will start with definitions that have recently been clarified by Petzold et al. [6] with respect to the types of carbonaceous particles.

\section{Black carbon $(\mathrm{BC})$}

Following Petzold et al [6], we use $\mathrm{BC}$ when describing the material identified through the characteristic aggregate morphology of combustion sourced particles. Very little qualitative information on mass is achieved using morphology, and so the general qualitative term $\mathrm{BC}$ has been maintained for morphologic methods. This term has historically been used to describe those refractory carbonaceous particles that strongly absorb light at all solar wavelengths as reflected in a recent EPA report to congress [7] stating "In this report, $\mathrm{BC}$ is defined as the carbonaceous component of particulate matter that absorbs all wavelengths of solar radiation;" where all wavelengths of solar radiation corresponds to "the solar wavelengths present in the troposphere (eg, 280-2500 nm)." Bond et al. [8] provide a refined definition as " $a$ distinct type of carbonaceous material that is formed primarily in flames, is directly emitted to the atmosphere, and has a unique combination of physical properties." Bond et al. [8] and Petzold et al. [6] describe four fundamental physical properties of BC:

1. Strong visible wavelength-independent light absorption with a mass absorption coefficient (MAC) of at least $5 \mathrm{~m}^{2} \mathrm{~g}^{-1}$ at $550 \mathrm{~nm}$

2. Refractory with vaporization temperature near $4000 \mathrm{~K}$

3. Graphitic $\mathrm{SP}^{2}$-bonded carbon with aggregate morphology

4. Insolubility in water and common organic solvents

Petzold et al. [6] recommend that ' $\mathrm{BC}$ ' should be used only as a qualitative and descriptive term when referring to lightabsorbing carbonaceous particles and should be avoided when describing measurements with evolved gas methods. Given that the term $\mathrm{BC}$ has been so widely used by the modeling and assessment communities, its use will be unavoidable but some mitigation is possible as long as additional description is given as to how it is measured.

Elemental carbon (EC)

This is the component of carbonaceous particles that is thermally stable in an inert atmosphere up to approximately $4000 \mathrm{~K}$. It can only be oxidized at temperatures $>340{ }^{\circ} \mathrm{C}$ [9]. $\mathrm{EC}$ can be derived from evolved gas analyzer (EGA) measurements, aerosol mass spectroscopy, and Raman spectroscopy measurements [6].

Equivalent black carbon (eBC)

A number of commercial instruments that measure the absorption coefficient of absorbing particles derive a mass concentration of "BC" using a conversion constant referred to as a mass absorption coefficient (MAC). In order to clarify that what is being measured may not be $100 \%$ BC, Petzold et al. [6] recommend the use of $\mathrm{eBC}$ when reporting the carbon mass derived from the absorption coefficient.

\section{Refractory black carbon (rBC)}

The carbon mass derived from laser induced incandescence (LII) is referred to as refractory black carbon since it is derived by measuring the thermal emission of the carbon component of the particle that absorbs the laser energy.

\section{Light absorbing carbon (LAC)}

The carbon component of atmospheric aerosol that strongly absorbs light at visible wavelengths [10, 11], including eBC and brown carbon.

Organic carbon (OC)

This is the component of carbonaceous particles where the carbon molecules are chemically combined with hydrogen and other elements like oxygen, sulfur, etc. [12]. OC can be derived from several different methods and is also an operational definition for EGA measurements.

Total carbon (TC)

This is the sum of OC and EC derived from EGA measurements.

Brown carbon $(\mathrm{BrC})$

The light-absorbing OC in airborne aerosols of various origins, which tends to appear brown rather than black $[10,13$, 
14]. Their color is a result of non-uniform absorption over the visible wavelength range.

\section{Measurement techniques}

Throughout the remainder of this review, the focus will be on the measurement of EC, LAC (as a pathway to $\mathrm{eBC}$ ), $\mathrm{eBC}$ and $\mathrm{rBC}$. The general structure of the presentations for each measurement technique is (1) a brief description of the measurement principle, (2) discussion of how the principle is applied in practice, (3) cautionary notes on the limitations and uncertainties associated with the technique and interpretation of the measurements, and (4) a list references for further reading (these are combined in the reference section at the end of the paper).

\section{Elemental carbon (EC)}

Thermal and thermal optical analysis Thermal analysis techniques, commonly referred to as evolved gas analysis (EGA), require the deposit of the sample of interest on a filter or aluminum substrate. This is placed in an oven where it is heated over a period of time, in different stages, where each stage represents a different temperature. The property of EC that is being used as a measure of its concentration is its high oxidation temperature, $>470{ }^{\circ} \mathrm{C}$, compared with the lower temperatures that will volatilize $\mathrm{OC}$ and inorganics. Depending on the particular technique that is implemented, the heating is done in an oxidizing or an inert atmosphere where the number of stages and the temperature at each stage also depends on the protocol that is selected. The word "protocol" is used here in the context of what different monitoring programs have selected as optimum setting for analysis of filters taken at the stations within their network. In the US, the two most commonly used protocols are the National Institute for Occupational Safety and Health (NIOSH) Method $5040[15,16]$ and the Interagency Monitoring for Protected Visual Environments (IMPROVE) method [17, 18], respectively. Other countries' monitoring programs have implemented similar protocols.

The implementation of the thermal analysis is shown in Fig. 1. It illustrates the basic steps for achieving a separation between OC and EC. Steps 1 through N-1 are designed to remove the carbon molecules associated with the $\mathrm{OC}$ by heating the sample in a non-oxidizing atmosphere so that the $\mathrm{OC}$ is volatilized and converted to carbon dioxide $\left(\mathrm{CO}_{2}\right)$ as it passes over a manganese dioxide $\left(\mathrm{MnO}_{2}\right)$ catalyst and is then measured, either with a $\mathrm{CO}_{2}$ analyzer or converted to methane and quantified with a flame ionization detector (FID). The last step substitutes an oxidizing gas for the inert gas so that the remaining carbon combusts. Although this measurement can be made in just two steps, $\mathrm{N}$ is usually greater than two because $\mathrm{OC}$ will volatilize at varying temperatures, depending upon its source and composition; hence, providing additional information about the evolved $\mathrm{OC}$ at different temperatures. The laser shown in the Fig. 1, and the associated detectors, are used to make corrections to the measurements attributable to problems inherent in the techniques that are described below.

The advantage of this technique is that the measurement principle and its implementation are straightforward; however, there are a number of limitations associated with its implementation that complicate the interpretation of the results and introduce uncertainties that cannot be completely minimized. An excellent discussion of these limitations and uncertainties can be found in Watson et al. [19].

The separation of EC from OC would be simplified if there were a distinct temperature below which no $\mathrm{EC}$ would combust and above which no OC would volatilize. This is not the case since the process of heating the $\mathrm{OC}$ can cause some fraction of it to char by pyrolysis. This pyrolyzed carbon will no longer volatilize and, instead, combusts during the final temperature stage, incorrectly being measured as EC. In an attempt to determine how much of the OC pyrolyzes, the sample on the filter is illuminated with a laser and the amount of light transmitted or reflected is measured. The EC on the filter will absorb some of the incident light and as the char is formed it will also absorb light so that the measured transmission or reflectance will be seen to decrease. During the final stage of heating, the pyrolyzed $\mathrm{OC}$ and $\mathrm{EC}$ will begin to combust, removing the light-absorbing carbon so that the transmission or reflectance is seen to once again increase. When the measured transmitted or reflected light returns to its initial value, it is assumed that all carbon combusted after this point is only EC. The two techniques using transmitted or reflected light are referred to as thermal optical transmittance (TOT) $[16,20]$ or thermal optical reflectance (TOR) [18, 21], respectively. The analytical limit of detection for these two techniques is about $0.2 \mu \mathrm{g} \mathrm{cm}^{-2}[17,20]$.

There are various interferences that introduce uncertainties into the determination of the exact temperature at which only EC is being measured. Some EC can be evolved during the inert gas stage as a result of the presence of various metal oxides (eg, $\mathrm{Fe}_{2} \mathrm{O}_{3}$ ) that will oxidize the $\mathrm{EC}$ [22]. In addition, complicating the interpretation of the TOT or TOR is that not all pyrolyzed OC will absorb at the wavelength of the laser [23]. There are additional problems related to the location of the temperature sensor in the oven with respect to the sample since the amount of time the oven is kept at a constant temperature is dependent upon how quickly the sample reaches the set temperature.

The calibration of this method can only be done to determine the response of the analyzer to a known quantity of an OC like sucrose that is put onto a filter, weighed, and then analyzed in the instrument. There is no generally accepted method for calibrating the response of the thermal method to EC since the community has yet to agree on a standard reference material (SRM) [24]. The general features of the thermal analysis measurement technique are listed in Table 1. 
Fig. 1 This diagram illustrates that the derivation of organic and elemental carbon using thermal optical analysis requires multiple stages of heating at different set temperatures and with different carrier gases
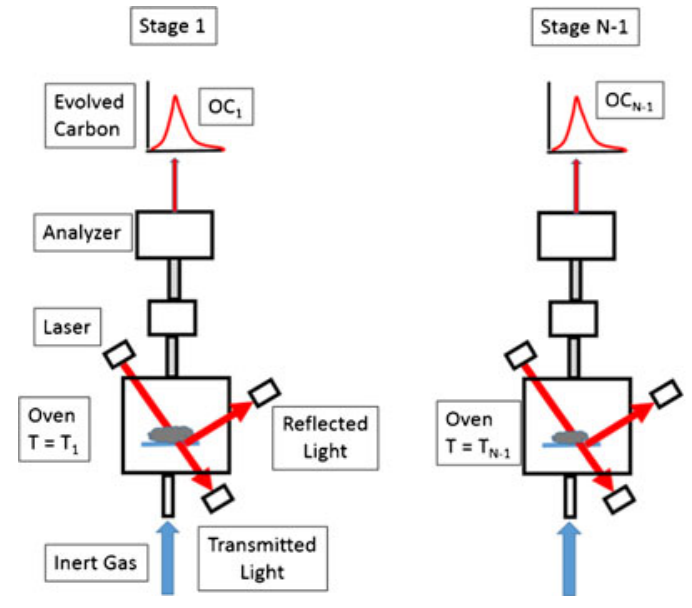

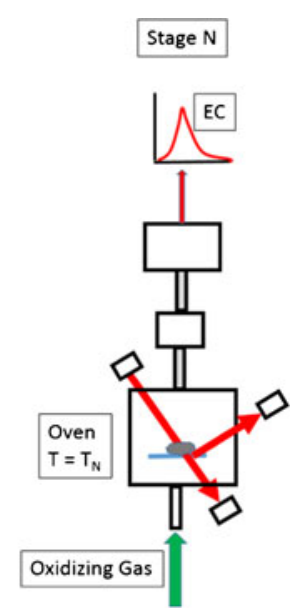

For further reading: (1) experiments that have compared the different thermal methods: [23, 25-30]; (2) interferences from inorganic material: [31-33]; (3) sources of other limitations and uncertainties: [25, 28, 34-36].

Raman spectroscopy Raman spectroscopy (RS) measures the inelastic scattering of light when the vibrational mode of a chemical bond shifts the wavelength of some of the incident light. RS is very selective towards the hexagonal lattice structure of SP2-hydridized carbon, although a range of vibrational modes around a peak energy is observed, RS provides sensitive information on the structural order of atoms within systems that can show crystalline (ordered) or amorphous (disordered) properties and is very selective towards the hexagonal lattice structure of $\mathrm{SP}^{2}$-hydridized carbon [37]. When a long-range order of these hexagonal lattices exists, the material is referred to as graphite. The solid carbon produced from combustion of fossiland bio-fuels results in short range (or disordered) hexagonal lattices [37]. Carbon-carbon (C-C) bonds within an intact hexagonal lattice produce characteristic RS modes at $1585 \mathrm{~cm}^{-1}$ (referred to as the ' $\mathrm{G}$ ', or graphitic, mode), whereas $\mathrm{C}-\mathrm{C}$ bonds at the edges of crystals (incomplete hexagonal

Table 1 Thermal optical analysis technique summary

\begin{tabular}{ll}
\hline Measures & EC \\
\hline Units & Mass \\
Collection media & Filter substrate \\
Collection time & Hours \\
Uncertainty & $\pm 20 \%-50 \%$ \\
Calibration & Currently no generally accepted method to \\
& calibrate EC. It can be calibrated to model \\
& compounds but there is no generally \\
& accepted method for calibration to \\
& atmospheric EC. \\
Biases & Pyrolysis, inorganics \\
Measures BrC & No \\
\hline
\end{tabular}

lattice) produce RS modes at $1620 \mathrm{~cm}^{-1}$ and $1360 \mathrm{~cm}^{-1}$ [38-40] ('D', or disordered, modes). Because $\mathrm{SP}^{2}$-hybridized carbon contains only $\mathrm{C}-\mathrm{C}$ bonds, these modes are highly selective to the occurrence of just EC.

Subtle differences in the RS modes can provide detailed information on the size and morphology of graphite crystals, and therefore, some contend, can provide source attribution, as morphology can change with combustion conditions [37, 41]. The modes, however, can also change because of other materials within the sample matrix. This is potentially an issue for combustion-sourced EC where common co-emitted species (such as organic matter) contain varying ratios of $\mathrm{SP}^{2}$ and $\mathrm{SP}^{3}$-hybridized carbon continuum [37, 39, 41]. Commercially available graphitic and organic materials are available to provide reference RS spectra [39, 42], some which show similarities to those of atmospheric EC [42].

The G mode intensity scales with crystal size [39], light absorptivity [43], and mass of EC [42, 44] in the bulk sample and so there is potential to use RS to quantify the absorptive properties and mass concentrations of EC. Rosen et al. [43] presented a semi-quantitative relationship of RS signals and light absorption. They integrated the area of the RS modes around $1600 \mathrm{~cm}^{-1}$ and compared this to the light transmission through a filter, which can be corrected to produce a measure of absorption. Keller and Heintzenberg [44] used the ratio of intensities of the modes $1601 \mathrm{~cm}^{-1}$ and $888 \mathrm{~cm}^{-1}$ to linearly correlate RS response to graphitic carbon mass. Mertes et al. [42] integrated the area of the RS modes around from $1510 \mathrm{~cm}^{-1}$ to $1736 \mathrm{~cm}^{-1}$ to quantify the mass of atmospheric EC on a filter. To achieve this, they calibrated the RS responses to known masses of a commercially available calibration material that displayed similar RS properties to atmospheric EC (see Figs. 2 and 3). Uncertainties of up to $13 \%$ in RS derived EC mass were reported [42]. If the calibration material does not match the spectral features of atmospheric EC, reported uncertainties will be larger. Ivleva et al. [41] and others have reported that organic components can show RS modes at around $1500 \mathrm{~cm}^{-3}$, which may interfere with the 


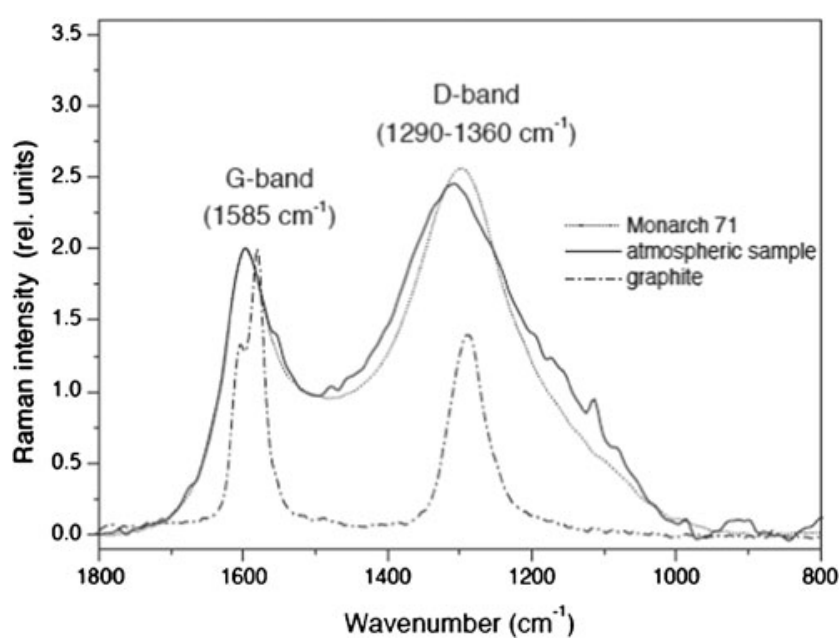

Fig. 2 Figure 1 from Mertes et al. [42]. Raman spectra of graphite (dashed dotted line), Monarch 71 (dotted line), and GC contained in atmospheric aerosol particles (solid line)

wavenumber integration range used for the quantification of EC by Mertes et al. [42]. Organic material can produce high background fluorescence in RS, which can influence curvefitting routines and limit the quantitative ability of the approach [41]. Ivleva et al. [41] did show a robust negative correlation between the relative content of EC to total carbon and the FWHM of the D band at $1350 \mathrm{~cm}^{-1}$ with organics appearing as an outlier to this relationship, potentially providing a semi-quantitative measure of the influence of organic material to the RS analysis of EC mass.

Overall, the RS technique, although providing very specific identification of EC in a sample, has had limited application to

\section{S. Mertes et al. / Aerosol Science 35 (2004) 347-361}

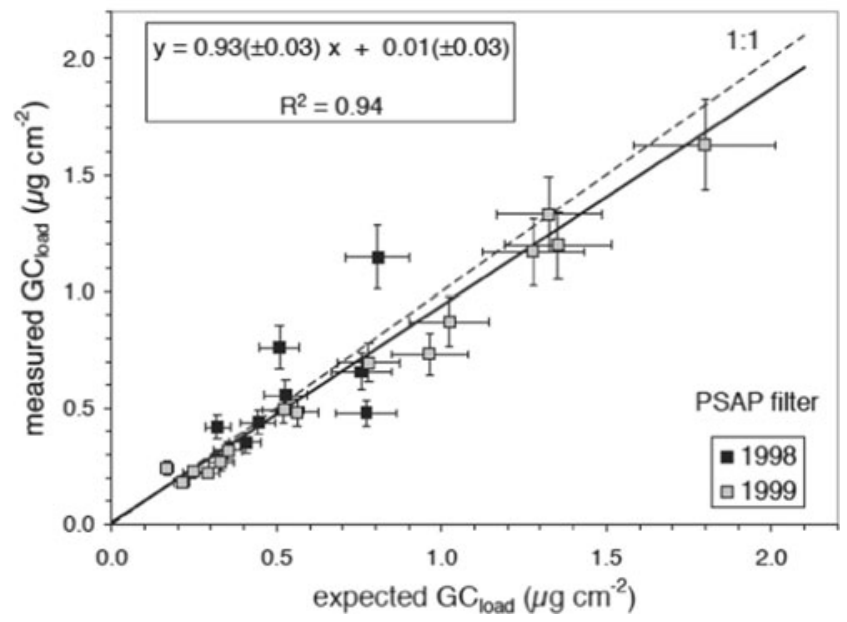

Fig. 3 Figure 4 from Mertes et al. [42] comparing GC mass loadings on the PSAP glass fiber filters and simultaneously operated polycarbonate filters from ambient sampling. The expected $\mathrm{GC}_{\text {load }}$ values (x-axis) are calculated from the GC mass loadings measured on the polycarbonate filters. Regression results (straight line) and the 1:1 line (dashed line) are indicated the quantification of EC. One major drawback of the technique is that the analysis of RS spectra usually requires curve fitting to multiple convolved spectral features. To achieve robust fitting high signal-to-noise is required; therefore, a sufficient quantity of sample must be collected [37, 39]. To achieve this for atmospheric samples, tens of minutes to multiple hours [42] of sampling are required making RS an impractical technique for real time atmospheric sampling requiring high time resolution. As mentioned, interference by fluorescence of some materials limits the ability to provide accurate curve fitting and so care must be taken that sample collection is not done using a fluorescing filter medium [39]. Sufficiently high laser power can also damage samples, although signal to noise can be improved with higher laser powers. Care should be taken to balance these trade-offs [39]. The general features of the Raman spectroscopy measurement technique are listed in Table 2.

Insolubility At room temperature, EC is an inert substance, insoluble in polar and nonpolar solvents including acids, bases, and organic solvents. While this property is often cited as a defining characteristic of EC [6, 46], very little work has been done to develop this characteristic into a measurement method. For the analysis of OC, solvent extraction with polar and nonpolar solvents is often used to extract fractions of OC from filter samples [47-49]. Apple et al. [50] have obtained an upper limit estimate of the EC fraction in atmospheric aerosol sampled on glass fiber filters from the carbon remaining insoluble after a two-step extraction process. While we are not aware of any attempt to further develop this estimation into a quantitative measure of EC concentrations, insolubility has potential for separating EC from OC if a suitable protocol with appropriate solvents can be formulated and tested. The general features of the Insolubility measurement technique are listed in Table 3.

Equivalent black carbon via measurement of light absorbing carbon (LAC)

Light absorption by particles has been used extensively to derive a mass of $\mathrm{eBC}$ requiring the conversion of the light absorption

Table 2 Raman spectroscopy technique summary

\begin{tabular}{ll}
\hline Measures & EC by calibration \\
\hline Units & Mass \\
Collection media & Filter substrate \\
Collection time & Hours \\
Uncertainty & $\geq 13 \%$ \\
Calibration & Commercially available material can \\
& provide calibration for RS spectra \\
Biases & and derived EC mass \\
Measures $\mathrm{BrC}$ & Possibly co-emitted organics \\
\hline
\end{tabular}


Table 3 Insolubility technique summary

\begin{tabular}{ll}
\hline Measures & EC solvent extraction \\
\hline Units & Mass \\
Collection media & Filter substrate \\
Collection time & Hours \\
Uncertainty & Unknown \\
Calibration & Untested \\
Biases & Unknown \\
Measures BrC & No \\
\hline
\end{tabular}

coefficient to mass, via a mass absorption coefficient (MAC). The MAC of atmospheric air masses containing $\mathrm{BC}$ can vary with source and can be highly variable. Bond and Bergstrom [11] provide an extensive review of the literature and concluded that the MAC of freshly emitted BC from fossil fuel combustion is $7.5 \pm 1.2 \mathrm{~m}^{2} \mathrm{~g}^{-1}(550 \mathrm{~nm})$, whereas MACs for a variety of $\mathrm{BC}$ containing air masses can range upwards of $15 \mathrm{~m}^{2} \mathrm{~g}^{-1}$.

In recent years, it has been recognized that there are multiple contributors to atmospheric particle light absorption that may alter or bias the MAC of atmospheric BC $[10,11,49]$. BC and mineral dust were thought to be the main particle absorbers until recent research into the intrinsic absorptive properties of organic carbon showed that absorption can occur at some specific short, visible wavelengths (called brown carbon, $\mathrm{BrC}$ ) [10]. Additionally, the enhanced $\mathrm{BC}$ absorption by coatings on the $\mathrm{BC}$ (internal mixing) has been demonstrated theoretically [51, 52], in the laboratory [53-55], and field settings [56-58]. Given this, it must be recognized that any assumption that an absorption method is measuring exclusively $\mathrm{BC}$ must be questioned. When the contribution of these non-BC absorbers is unknown, and a BC MAC is applied, the non- $\mathrm{BC}$ absorption is converted to a $\mathrm{BC}$ equivalent, thus the source of the term "equivalent BC," described here and by Petzold et al. [6]. This treatment could bias the derived $e B C$ mass high compared with the methods outlined in other sections, particularly for commercial instruments that use a single MAC to convert light absorption to $e B C$ mass. There is evidence that for measurement of fresh combustion particles that this bias is within the uncertainties of the measurement methods $[8,58]$. For instruments that measure light absorption but derive a $\mathrm{BC}$ mass by applying a single MAC to all air masses, care must be taken to determine whether the manufacturer applied MAC is appropriate.

These biases may be reduced by determining individual contributions to total absorption. Contamination from dust can usually be determined by a combination of air mass trajectory modeling, particle size measurement or absorption wavelength dependence $[53,59,60]$. Contributions of $\mathrm{BrC}$ and internal mixing have been determined using a variety of methods [61-63], however, the multi-wavelength extrapolation methods that have often been applied contain significant uncertainties that should be considered before quantitative attribution is reported [62]. An alternative to measuring these contributions is to minimize them by sample pretreatment such as sample heating to vaporize the semi-volatile materials that lead to increased absorption by internal mixing or $\operatorname{BrC}[57,62,64]$.

The following sections detail the common filter-based and in-situ particle absorption measurement methods and presuppose that (a) the contributions of non-BC absorbers are adequately considered, and (b) an acceptable community standard MAC is applied to derive $e B C$.

Filter transmission measurements The darkening of filters loaded with absorbing atmospheric particles is commonly used to measure particle absorption. The intensity of light measured before $\left(\mathrm{I}_{0}\right)$ and after (I) passing through a filter (of thickness $x$ ) loaded with particles can produce an absorption coefficient of the particle-filter system $\left(b_{p f}\right)$, according to the Beer-Lambert law:

$I=I_{o} e^{-b_{p f} x}$

Instruments that use this filter transmission technique determine the absorption coefficient of the system by knowing the surface area of the collection filter (A), the flow rate of air passing over the filter $(V)$, the sample time interval $(\Delta t)$, and the light intensities at the beginning and end of $\Delta t[46,65-71]$ :

$b_{p f}=\frac{A}{V} \frac{\ln \left(\frac{I_{o}}{I}\right)}{\Delta t}$

True absorption can only be measured if there is no light scattered off the filter matrix that can be interpreted as absorption. This method also relies on the sample layer being thin to avoid multiple scattering effects of radiation between particles [72]. In practice, these conditions are rarely met, so significant effort to minimize or characterize and correct for these artifacts is necessary to produce accurate $b_{A b s}$ values [eg, 45, 65, 67]. The following corrections are likely necessary for correction of measured transmission to light absorption:

1) Multiple light scattering within the filter:

Incident light can scatter from the unloaded filter matrix (membrane or fibers) and increase the sample path, $x$ [73]. This will be dependent on filter type and optical configuration of the instrument $[46,71,74]$.

2) Filter Loading:

As the filter becomes loaded with absorbing particles, the incident light is absorbed and less light is passed through the filter, which is the basis for the measurement. However, as loading builds, the sample path (x) is decreased, leading to a bias in the calculated $b_{A b s}[66,71]$. This correction is dependent on the amount of absorbing material loaded onto the filter and dependent on the particle 
optical properties (eg, single scatter albedo (SSA) and particle size $[65,70,71]$, which are highly variable depending on source, transport, processing etc. [71, 75-79].

3) Particle Scattering Correction:

As the filter is loaded with scattering particles, incident light is scattered in all directions. This leads to higher filter reflectance and more opportunities for absorbing particles to absorb light. This correction will be dependent on total particle scattering (shape, size, composition, mass) $[65,66]$. For the particle soot absorbing photometer (PSAP), approximately $2 \%$ of particle scattering is interpreted as absorption $[65,70]$, whereas the choice of the Aethalometer filter introduces somewhat less of a scattering artifact [73].

In addition to the corrections, these methods require careful calibration of the filter surface area (A), sample flow rate (V) $[65,66,71]$, and may have biases due to liquid-like organics spreading across filter fibers [80-82]. This phenomenon introduces one of the limitations of the filter-based methods in that the particles deposited on the filter may change morphology [46], a property that contributes to both scattering and absorption. Additionally, artifacts related to elevated relative humidity and pressure and temperature fluctuations can influence the quality of measurements [83]. See Fig. 4 for a schematic of the radiation pathways for these methods.

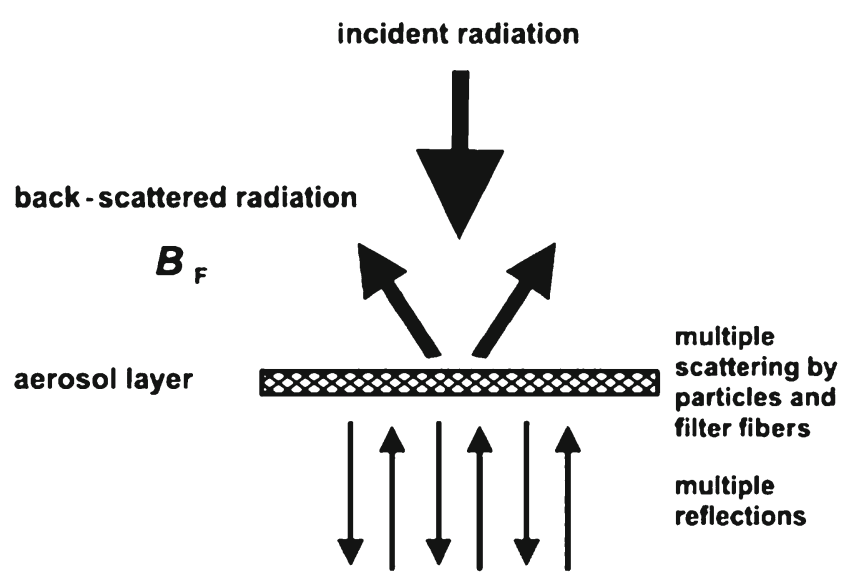

filter matrix

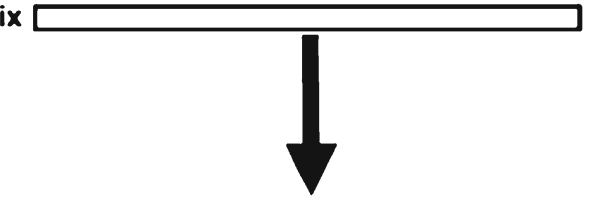

transmitted and forward scattered radiation

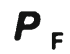

Fig. 4 Schematic of the MAAP radiation pathway, highlighting the forward and backscattered radiation, the multiple scattering within the particle layer and filter. Aerosol Science and Technology: Evaluation of multiangle absorption photometry for measuring aerosol light absorption. (39):40-51. Copyright 2005. Mt. Laurel, NJ., Reprinted with permission
There are numerous applications of the filter transmission method. The integrating plate (IP) [68] or integrating sandwich (IS) [84] methods use optical diffusors to measure the scattered radiation to enable scattering corrections. The IP and IS methods also utilize a membrane filter (with a refractive index that is close to that of atmospheric particles) for sample collection and, therefore, minimizes multiple scattering effects inherent to fiber filters. However, because of the sharp filtersample interface, the filter loading correction can become significant. The IP and IS methods also do not measure continuously, therefore requiring sample collection followed by offline data collection. Detailed discussions on these particular techniques are provided by Clarke et al. [85], Heintzenberg et al. [86], Horvath [87], and Reid et al. [88].

Advances to the IP and IS methods include instruments such as the aethalometer [67, 71], PSAP [65], and the continuous soot monitoring system (COSMOS) [89]. There are also a number of PSAP variants in use; the continuous light absorption photometer (CLAP; US National Oceanic and Atmospheric Administration, Global Monitoring Division), the PSAPITM [90], and the spectral optical absorption photometer [SOAP, 91]. These instruments sample continuously (seconds resolution) over multiple wavelengths, and often have multiple filter spots or automated filter changes for continuous field operation. One downside of these methods is the use of fiber filters that introduce varying degrees of scattering corrections larger than those of the membrane filters used by the IP and IS methods. These methods require significant laboratory experiments using a reference absorption method to determine appropriate correction factors $[66,70,71,83,89,92-94]$. Ultimately, these correction factors lead to measurement uncertainties of $20 \%-30 \%$ [8]. Of these techniques, the aethelometer and PSAP are the most commonly used commercial multiwavelength instruments. Collaud Coen et al. [66] and Virkkula and co-workers [70, 94] provide the most detailed discussions on the aethelometer and PSAP, respectively.

It should be noted that the use of these multi-wavelength instruments for interpreting absorption by $\mathrm{BC}$ and $\mathrm{BrC}$ is not advised, particularly for conditions where $\mathrm{BrC}$ does not contribute a significant amount of absorption. Both Collaud Coen et al. [66] and Virkkula et al. [70] point out that there are wavelength-dependent correction factors, whereas Lack and Langridge [62] show the uncertainties of using these multiwavelength attribution methods.

Recently, Petzold and co-workers [45, 69] introduced the multi-angle absorption photometer (MAAP), which measures, at multiple angles, the back-scattered light that is used in a radiative transfer model to provide the scattering corrections. In contrast to the other methods, the MAAP does not use empirical corrections. Using this method, they reported that filter loading and multiple scattering artifacts were significantly reduced. The MAAP has a reported uncertainty of about $12 \%$ (see Figs. 4 and 5 for the schematic of the MAAP radiation path 
Fig. 5 Comparison of MAAPmeasured absorption coefficients with those measured by the difference method, PAS and PSAP. 1:1 line shown as dashed line. Aerosol Science and Technology: Evaluation of multiangle absorption photometry for measuring aerosol light absorption. (39):40-51.

Copyright 2005. Mt. Laurel, NJ., Reprinted with permission

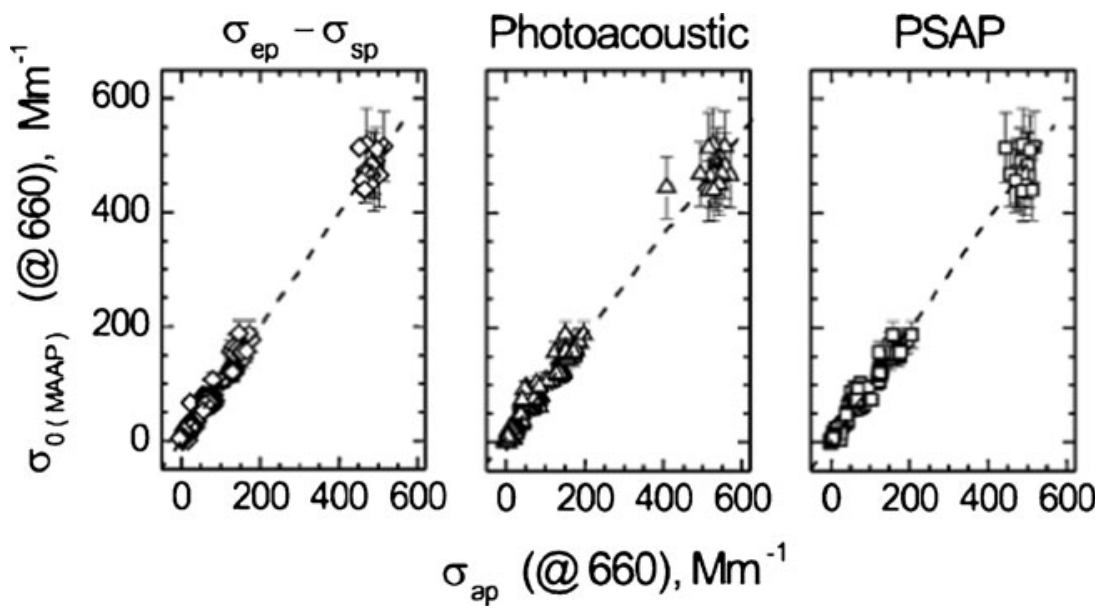

and comparisons of MAAP absorption with measurements from a PSAP and a photo-acoustic spectrometer (PAS), the latter instrument discussed in the following section.

Although significant work has been done on the measurement corrections for a variety of filter-based absorption instruments, there is still variable quality of $b_{A b s}$ measured by filterbased methods compared with a $b_{A b s}$ standard, such as the photo-acoustic method (e.g., [96, 97]), the difference of extinction and scattering method (e.g., 64, 96]), or the MAAP [66, 69, 97]. Controlled laboratory measurements of simplified $\mathrm{BC}$ particles or fresh fossil fuel combustion particles usually provide acceptable comparisons, whereas complex particles from a variety of sources can produce deviations from the reference methods [45, 53, 70, 79, 81, 83, 92, 98-103].

We note here that there are other commercial applications of the filter transmission method, particularly in industry applications where the qualitative Filter Smoke number (e.g., [104]), or Bosch number measurements are used to determine exhaust opacity. We note that these measurements, although used under standardized protocols (ISO8178), have not been subjected to the same rigorous artifact corrections as the aethelometer, PSAP, COSMOS, or MAAP.

Advantages of these well-characterized methods include insensitivity to gas phase absorption and simple, inexpensive operation. The disadvantages included the added uncertainty of the measurement because of the required corrections and the removal and potential alteration of the particles from their suspended state. The general features of the filter-based absorption measurement technique are listed in Table 4.

Photo-acoustic techniques Thermal measurement techniques, including photo-acoustic and interferometric (see following section) techniques are very direct, in situ measurements of the aerosol absorption coefficient at the wavelengths of the light source(s) employed. They quantify the fraction of absorbed optical energy that is rapidly transferred into the surrounding air as illustrated in Fig. 6 for the photo-acoustic technique [46]. Light, generally in the form of a laser beam, is incident on a particle suspended in air (Fig. 6a); some of the light is transmitted, some scattered, and if the particle has a non-zero imaginary component of the refractive index, some is absorbed and heats the particle (Fig. 6b). For small particles, the heat is rapidly transferred to the surrounding air (Fig. 6c), and if the incident light is power-modulated, an outgoing acoustic wave at the modulation frequency is generated [46]. Generally, an acoustic resonator is employed to enhance the acoustic signal and to exclude and reduce acoustic noise. The resulting acoustic pressure is quantified with a microphone where the resulting signal is proportional to the aerosol absorption coefficient [105].

To calibrate the photo-acoustic technique, the microphone signal needs to be related to the absorption coefficient of the sample. For this purpose, a sample with known absorption coefficient can be employed, for example a gas such as nitrogen dioxide [106], ozone [96], or oxygen [107, 108], which has a well-known absorption spectrum and that can be introduced into the sample volume at a controlled concentration. A related calibration method that does not rely on previously measured absorption coefficients and concentrations introduces an absorbing gas or aerosol with sufficiently high absorption coefficient so that the transmittance and thereby the extinction coefficient can be measured accurately. If

Table 4 Summary of measurement features of filter-based absorption

\begin{tabular}{ll}
\hline Measures & Absorption and $\mathrm{eBC}$ by MAE \\
\hline Units & $\mathrm{Mm}^{-1}$, Mass \\
Collection media & In situ \\
Collection time & Seconds \\
Uncertainty & $12 \%-30 \%$ \\
Calibration & Involves corrections requiring extensive \\
& laboratory experiments to derive eBC \\
Biases & Elevated RH, possible elevated levels of OC \\
Measures BrC? & Multi-wavelength units can provide qualitative \\
& to semi-quantitative estimates [62]
\end{tabular}




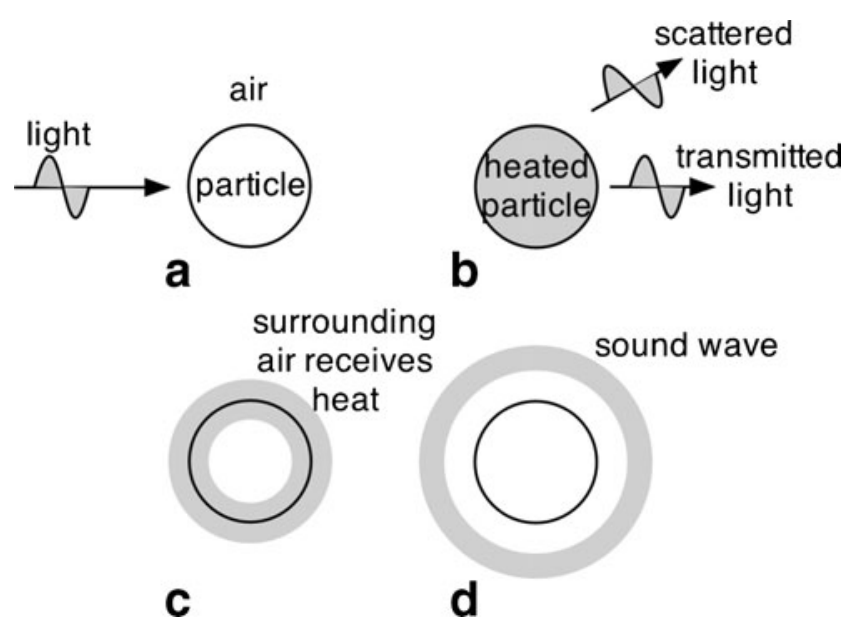

Fig. 6 (A) Light is incident on a particle. (B) Some of the incident light is absorbed by the particle, some is transmitted, and some is scattered. The particle is heated by light absorption. (C) Heat transfers from the particle to the surrounding air. (D) The surrounding air expands upon receiving heat, resulting in an outgoing acoustic wave if the incident light is powermodulated (from [46])

scattering can be neglected (generally true for gases), calibration can be achieved by assuming that the absorption coefficient equals the extinction coefficient. For aerosols, scattering cannot be neglected but the scattering coefficient can be measured with the reciprocal nephelometer [109] that is commonly integrated into photo-acoustic instruments and the absorption coefficient can be obtained by subtracting the scattering coefficient from the extinction coefficient. For the measurement of eBC, a correlation between $\mathrm{BC}$ mass and measured absorption needs to be established (e.g., [110, 111]). This is best done at a near-infrared wavelength where contributions of brown carbon to absorption are insignificant.

For gases, not all of the absorbed energy may be available as acoustic energy because it may be transferred into different pathways. This must be taken into account if the instrument is calibrated using gaseous absorption. One example of an alternate, energy-absorbing pathway is the photodissociation of the absorbing molecule, thereby reducing the acoustic signal. The photodissociation of nitrogen dioxide $\left(\mathrm{NO}_{2}\right)$, a frequently used calibration gas, is prevalent in the ultraviolet below $398 \mathrm{~nm}$ [112]. Another source of energy absorption is collision-induced relaxation that limits conversion of absorbed energy into acoustic energy. This is common for the oxygen molecule [108]. For the case of calibrating with particles, not all of the absorbed energy may be transferred into acoustic energy because (1) part of the energy is used to evaporated semi-volatile particle compounds such as water, thereby reducing the acoustic signal [113-116], (2) because for large particles, the time constant of heat transfer to the surrounding air [117] might be larger than the inverse of the power modulation frequency. In the latter case, the error can be detected and quantified by observing the phase shift of the acoustic signal [46]. Gaseous absorption of the aerosol sample will also contribute to the measured absorption coefficient. To obtain the absorption coefficient of the particles, wavelengths where gaseous absorption of air is minimized should be used. Any remaining gaseous absorption can be subtracted by periodically or continuously measuring the absorption of particle free (ie, filtered) air [118].

Several research groups and companies have built and are using photo-acoustic instruments for the measurement of aerosol light absorption. Early efforts were often hindered by the use of very large and power-consuming lasers such as argon ion lasers (e.g., [119]), whereas more recently small and efficient diode lasers and diode-pumped solid state lasers are commonly used (e.g., $[118,120])$. Some early efforts used radial and azimuthal resonators [121-123], whereas currently longitudinal resonators of half- or full-wavelength length have become more common [46]. The influence of acoustic background noise has been reduced, for example, by placing sample inlets at nodes of the acoustic pressure [118], employing acoustic notch filters [118], using subtraction techniques employing two identical resonators with only one containing a laser beam [96], and by reducing noise from the sample pump with a critical orifice [46]. Such reduction of acoustic background noise, together with the use of phase-sensitive detection techniques and powerful lasers and optical multi-pass cells [96], has yielded detection limits for the measurement of aerosol light absorption below $0.1 \mathrm{Mm}^{-1}$ (60 s averaging time) and an instrument accuracy of $\sim 5 \%$ [96]. In addition, the ongoing development of multi-wavelength photo-acoustic instruments [124-128] is important for characterizing the wavelength dependence of aerosols such as brown carbon and mineral dust [46].

Photo-acoustic instruments have been used for characterization of aerosols in ambient air with instruments deployed stationary and on vehicles, including airborne deployment [46]. The early characterization and measurement of eBC and the calibration of filter-based measurements (e.g., [80, $81,92])$ have been complemented with characterization of brown carbon [63, 124, 129-132] and mineral dust [133], and the investigation of the role of particle coatings $[53,63$, $132,134]$, morphology [135], and humidity induced particle collapse [136] on light absorption. While photo-acoustic instruments have become the "standard" for the accurate measurement of aerosol light absorption [97], deployment is still limited compared with filter-based instrument, and part of their utility has been in improving the calibration of filterbased measurements. The general features of the photoacoustic measurement technique are listed in Table 5.

Interferometric techniques Light absorption can be measured by photo-thermal methods that alter the density and refractive index (RI) of air molecules or particles that absorb laser radiation [137]. Photo-thermal interferometry $\left(\mathrm{PTI}^{1}\right)$ is the

\footnotetext{
${ }^{1}$ Here we use PTI for the methods originally described as phase fluctuation optical heterodyne/homodyne spectroscopy (PFLOHS)
} 
Table 5 Summary of measurement features of photo-acoustic techniques

\begin{tabular}{ll}
\hline Measures & Absorption and eBC by calibration \\
\hline Units & $\mathrm{Mm}^{-1}$, Mass \\
Collection Media & In situ \\
Collection time & Seconds \\
Uncertainty & $5 \%$ \\
Calibration & Calibration aerosols and gases \\
Biases & Large particles ( $>2.5$ um), elevated RH \\
Measures BrC & At appropriate wavelengths, with \\
& appropriate sample conditioning \\
\hline
\end{tabular}

method most commonly used to measure particle absorption [138-141] and is the focus of this review section.

When particles absorb radiation, the energy is returned to the surrounding air by collisional quenching, which heats the air leading to gas expansion, gas density changes, and RI changes [141]. These changes are measured using an interferometer, where two identical laser beams (split from the same source) pass through almost identical geometric paths. The only difference in beam paths is that the 'probe' beam travels through the sample volume and is then recombined with the second 'reference' beam after which an interference pattern is measured. When the sample is heated with a 'sample' laser (modulated at frequencies $<100 \mathrm{~Hz},[142,143]$ ), the optical path length of the probe beam changes because of the gas density change, which leads to a phase shift between the probe and reference beams, observable in the interference pattern. This phase shift is proportional to the RI change of the sample air, and the amount of energy absorbed by the sample [141, 142, 144, 145].

Theoretically, PTI can achieve detection limits two orders of magnitude lower than PAS [144]; however, early implementations did not achieve such detection limits [96, 141, 142]. This can be attributed to unwanted changes in the optical path length from sample turbulence, temperature gradients, and mechanical vibrations [141, 142, 146]. Signal to noise can be improved by increasing sample and probe laser power and integrated sample volume [141-143], although particle components, including water at elevated $\mathrm{RH}$, can volatilize and create measurement biases (also common to PAS) when subjected to excessive laser power [142, 145]. Probe beam modulation frequency can also be chosen within a certain range to avoid mechanical vibrations, whereas the probe laser wavelength can be chosen to avoid absorption of specific gas or particle species [141, 142, 147, 148].

The PTI signal is linear with high concentrations of absorbing species [141, 145]; however, sample saturation can occur when the phase change between probe and reference beams becomes too large [142] and when the particles are too large to transfer the absorbed energy to the surrounding air within the probe beam modulation period (an issue common to PTI and PAS) [141, 142]. Measurements of sub-micron particle properties and sample dilution can successfully avoid these issues [141, 142, 145].

PTI calibration for particle absorption has been achieved in a number of ways. Lin and Campillo [141] and Sedlacek [143] measured the PTI phase shift of known concentrations of ethylene or $\mathrm{NO}_{2}$, utilizing the known absorption cross section of these gases to determine absorption. Particle mass, calculated from known particle diameters and number concentrations of mono-disperse ammonium sulfate particles, rather than absorption, was correlated to the PTI phase shift by Fluckiger et al. [142].

Due to fundamental instabilities in the various interferometer optical designs that make the technique susceptible to mechanical vibrations [141], the PTI technique has seen very limited application for measuring particle light absorption $[141,142]$. To overcome this issue, Moosmüller and Arnott [146] introduced a unique interferometer design that virtually eliminated these mechanical instabilities, the folded Jamin interferometer, and this design has proven to be capable of robust visible wavelength light absorption measurements by particles [143, 145, 149]. Sedlacek and Lee [145] showed a $10 \%$ uncertainty in measured absorption and $0.4 \mathrm{Mm}^{-1}$ detection limit (10 s sampling time), in addition to showing accurate comparisons to absorption measured by other techniques (PAS and PSAP). For absorption by particle from laboratory and ambient sources, comparisons of PTI and PSAP to within $4 \%$ were achieved (Fig. 7).

With these recent advances and other advantages over filterbased methods (ie, no particle scattering interferences [143]), and claims of superiority over PAS [142], PTI would appear to

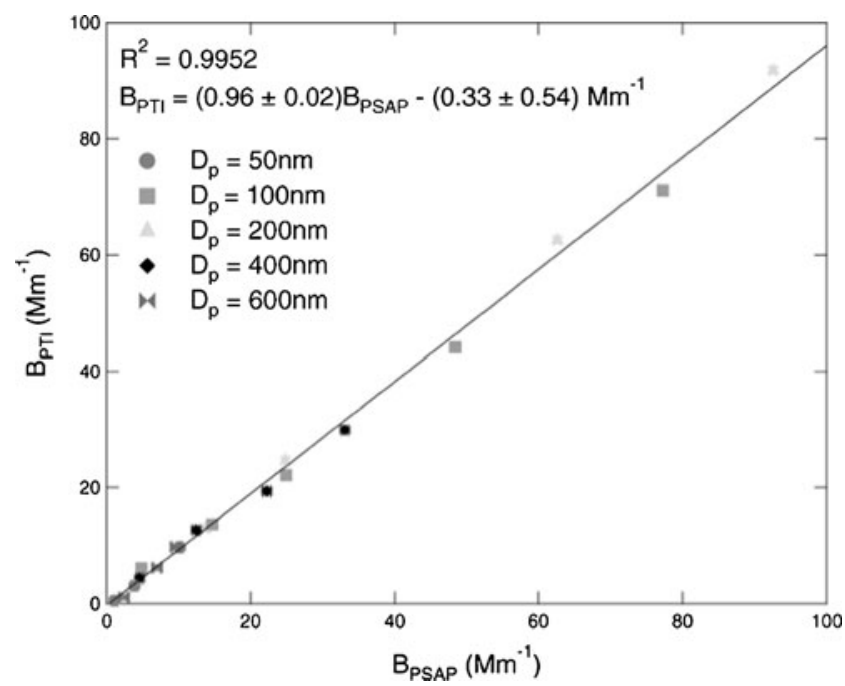

Fig. 7 Figure 3 from Sedlacek and Lee [145], plot of nigrosin absorption coefficients measured by the PTI and Aerosol Science and Technology: Photothermal interferometric aerosol 1813 absorption spectrometry. (41):1089-1111. Copyright 2007. Mt. Laurel, NJ., Reprinted with permission 
be a favorable advance for measuring particle absorption, particularly when multi-wavelength PTI instrumentation seems eminently possible [145]. Despite this, PTI remains a research tool with limited applications for measuring particle light absorption.

Comprehensive treatments of the theory of the PTI technique are presented in a number of studies (e.g., [138, 139, 141, 142]), while the technique also finds common application in metrology [150-153]. Moosmüller et al. [144] provided a review of PTI for particle absorption measurements following the critical advance of the folded Jamin interferometer by Moosmüller and Arnott [146]. Since these two publications, only the work of Sedlacek and coworkers [143, 145, 149] has provided any advance to the science on PTI measurement of particle absorption. The general features of the photo-thermal interferometry measurement technique are listed in Table 6.

Remote sensing measurements At the moment, eBC cannot be derived using remote sensing techniques, although a great deal of effort is being invested in finding the means to do so. If it is possible to remotely measure aerosol light absorption or single scattering albedo (SSA) at multiple wavelengths, it may be possible to distinguish between the dominant aerosol types that absorb in the visible and near-visible wavelengths, more specifically $\mathrm{BC}, \mathrm{BrC}$, and mineral dust [154]. The derivation of aerosol light absorption by remote sensing techniques has in itself been challenging with mainly multi-angle techniques showing success. Single-angle techniques such as monostatic lidar [155] or simple sun photometry [156] cannot distinguish the scattering and absorption components of extinction. Advanced high-resolution lidar [157-161] and Raman lidar systems [162-164] can measure aerosol particle extinction and backscatter coefficients; however, the $4 \pi$-integrated aerosol scattering coefficient cannot be derived from the aerosol backscatter coefficient without knowledge of the particlephase function that depends on the size distribution and refractive indices of the ensemble of particles that scatter and absorb the incident light. It has been found, however, that mineral dust aerosol extinction coefficients depend much less

Table 6 Summary of measurement features of photo-thermal interferometry

\begin{tabular}{ll}
\hline Measures & Absorption and eBC by calibration \\
\hline Units & $\mathrm{Mm}^{-1}$, mass \\
Collection media & In situ \\
Collection time & Seconds \\
Uncertainty & $10 \%$ \\
Calibration & Calibration gases of known concentrations \\
Biases & Large particles $(>2.5$ um), elevated $\mathrm{RH}$ \\
Measures $\mathrm{BrC}$ & With instrument development \\
\hline
\end{tabular}

on the imaginary part of the refractive index than mineral dust backscatter coefficients; hence, their ratio may provide some indication of mineral dust aerosol light absorption [165]. Multi-wavelength Raman lidar has been used for the retrieval of the SSA for spherical particles [166] and bi-static lidar systems may be able to derive significant parts of the aerosol phase function; hence, there is some potential for deriving light absorption by remote sensing, possibly in combination with sun photometry [167].

The retrieval of aerosol light absorption, using the measurement of diffuse and direct solar radiation [168], is being attempted with multi-angle and multi-wavelength observations of sun and sky radiances with sun and sky scanning radiometers, as implemented by AERONET [169] or multi-filter rotating shadowband radiometers such as those deployed by the ARM program [170, 171]. These retrievals require sophisticated inversion algorithms that are based on models of the vertical profiles of atmospheric particles and optical calculations of their properties for spherical or spheroidal particles. These retrievals yield column-averaged aerosol light absorption, which is commonly given either as SSA or absorption optical depth [172-175]. Spectral SSA data from AERONET have been used to derive concentrations of mineral dust iron and $\mathrm{BC}$ during dust and pollution episodes. Some of these retrievals show reasonable agreement with chemical analyses [176]. Measurements of aerosol light absorption with sun and sky radiometer networks are extremely useful for the characterization of aerosol light absorption for specific aerosol types and for determining their atmospheric distribution [154, 177, 178]. However, these observations yield column-integrated measurements and, therefore, "effective" values, potentially including different aerosols and mixing states. Additional comparisons of remote sensing with direct in-situ measurements of aerosol light absorption would be desirable.

The retrieval of aerosol light absorption from satellite measurements is even more challenging [179] because of the spatial and temporal variations of the earth's surface albedo that often dominates the measured radiances. Proposals have been made to use critical reflectance $[180,181]$ and sun glint over oceans [182], yet only UV measurements, originally designed for the monitoring of stratospheric ozone, are currently employed operationally, with accuracies that still remain open for debate. Critical reflectance methods and multiangle measurements are showing some promise, as are novel multi-angle, polarimetric measurements, whose objective are more accurate SSA retrievals.

Sensors that are currently being used to retrieve aerosol optical properties include the total ozone mapping spectrometer (TOMS) and the ozone-monitoring instrument (OMI). TOMS was deployed on board the Nimbus-7 (1979-1992), Meteor-3 (1991-1994), and Earth Probe (1996-2006) satellites. Data products from TOMS include the aerosol index (AI), calculated from the difference in surface reflectivities derived from two 
UV channels [183]. The AI, although effective for the detection of aerosols above land and ocean surfaces, including the detection of absorbing aerosols (ie, smoke and mineral dust) above ice, snow, and clouds [184], and qualitatively mapping the distribution of aerosol light absorption, does not provide a quantitative measure of aerosol light absorption. The TOMS observations, when used in conjunction with the moderate resolution imaging spectroradiometer (MODIS) [185] measurements in the visible spectrum, have been utilized to retrieve the SSA [186-188]. MODIS observations have also been used to implement the critical reflectance method $[180,181]$ for retrieving aerosol SSA [189]. The multi-angle imaging spectroradiometer (MISR), operating in the visible-near-IR spectrum, on board the Terra satellite (1999-present), is able to distinguish weakly- from strongly absorbing aerosol types by retrieving the SSA [190-193].

There was the expectation that the state of satellite aerosol light absorption retrieval would be improving after the 2009 launch of the aerosol polarimetry sensor (APS) on board the Glory satellite [194, 195]; however, this satellite experienced a launch failure and never reached orbit. APS data products, based on the multi-angle polarimetric capabilities [194, 196] were to include aerosol SSA in at least three spectral channels for fine and coarse modes with an SSA uncertainty of 0.03 . The general features of remote sensing measurement technique are listed in Table 7.

\section{Refractory black carbon}

Refractory black carbon is measured using laser induced incandescence (LII). LII occurs when light-absorbing particles are illuminated by intense radiation and heated to temperatures much higher than the surrounding air. The high temperature particles emit grey/blackbody radiation that can be detected and used to derive the mass of the illuminated particle or particles. At sufficient light intensities, particles are heated to their vaporization temperature (or boiling point), which for $\mathrm{rBC}$ is approximately $4300 \mathrm{~K}$ [197]. At this point, the energy absorbed is approximately balanced by the energy lost via vaporization and radiation. The LII signal decreases as the

Table 7 Remote sensing technique summary

\begin{tabular}{ll}
\hline Measures & Light absorption and extinction \\
\hline Units & Aerosol optical depth \\
Collection media & None \\
Collection time & Variable \\
Uncertainty & Unknown \\
Calibration & None \\
Biases & Unknown \\
Measures $\mathrm{BrC}$ & No \\
\hline
\end{tabular}

particle shrinks since less light is absorbed and emitted by the evaporating particle.

Investigations into $\mathrm{rBC}$ using LII fall into two sub-groups, those using pulsed lasers and those using continuous lasers. Interference during Raman spectroscopy measurements motivated the earliest LII work on rBC produced in flames [198]. Weeks and Duley [199] showed that LII signals could be related to particle size for carbon black; however, it was the subsequent theoretical and observational studies [200, 201] that showed that LII could be used to directly derive the rBC properties in flames. For example, Melton [200] showed that the magnitude of the incandescence signal could be related to the volume concentration of $\mathrm{rBC}$ in the measurement region.

The LII $\mathrm{rBC}$ experiments employ pulsed ( $20 \mathrm{~ns})$, high intensity lasers that illuminate a point source or a twodimensional measurement volume as illustrated in the example shown in Fig. 8 [202]. The ability to visualize the spatial distribution of $\mathrm{rBC}$ in the measurement volume was particularly useful for studies of combustion systems (e.g., [203]), particularly those investigating turbulent and/or flickering flames where slower, scattering-based approaches were insufficient [204]. The decay of the LII signal was related to the primary particle size [205] because of the dependence of the particle cooling behavior on surface area. LII was also combined with two-color pyrometry (measuring the light emitted over different wavelength ranges) to determine the temperatures of particles in combustion systems [206]. Pulsed LII has also been combined with light scattering measurements to investigate $\mathrm{rBC}$ morphology [207]. Besides rBC measurements in flame combustion processes, pulsed LII techniques were eventually applied to measurements of diesel emissions [208], laboratory-scale gas flares [209], dusts [210], and atmospheric rBC measurements (e.g., [211]).

Stephens et al. [212] developed an alternative method for measuring LII of single particles for the purpose of identifying particle composition using two-color pyrometry. Unlike previous pulsed LII systems, Stephens et al. [212] illuminated particles by passing them directly through a continuous, intracavity, solid-state laser beam. Their design also featured a detector to measure light scattered by individual particles, which was used to estimate their size. Although the main motivation for the instrument was the identification of particle types based on vaporization temperatures, Stephens et al. [212] also highlighted the technique's ability to measure atmospheric rBC. The design was eventually commercialized as the single particle soot photometer (SP2) and has been used for atmospheric $\mathrm{rBC}$ measurements for roughly the last decade. Figure 9 illustrates the configuration of the SP2 for illuminating single aerosol particles and measuring the scattered and emitted components of the light.

The high sensitivity and time resolution afforded by the single particle measurements provided by the SP2 make the instrument suitable for ambient measurements in pristine 
Fig. 8 From Michelsen et al. [202]. This schematic is showing the fundamental components of the experimental apparatus. Abbreviations are as follows: B: bandpass filter; $\mathrm{CB}$ : camera control box; CL: signal collection lenses; DG, digital delay generators; F: colored glass filter; HV: high voltage power supply; ICCD: intensified charge coupled detector; IL: imaging lend; LWDM: long working distance camera; M: $1 / 4$ meter monochromator; PD: photodiode; PMT: photomultiplier tube; SH: laser sheet forming optics; SL: adjustable slit; VCR; video cassette recorder

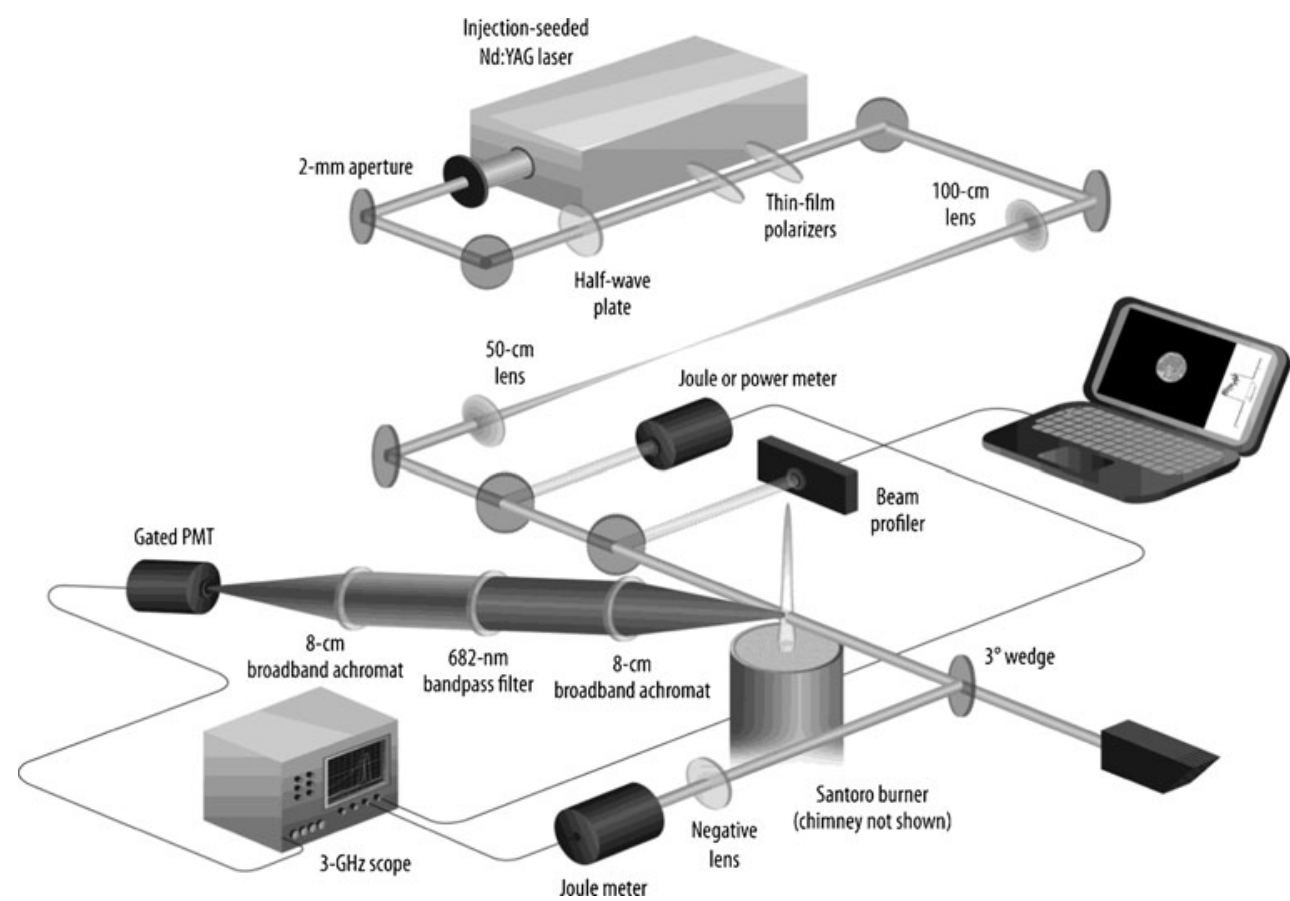

environments. The earliest applications of the SP2 focused on airborne characterization of $\mathrm{rBC}$ in the lower stratosphere/upper troposphere region $[95,213]$. The instrument was subsequently widely adopted for not only aircraftbased measurements but also field- and laboratory-based measurements of ambient rBC (e.g., [102, 214-216]). McConnel et al. [217] showed that the SP2 could be applied to measure $\mathrm{rBC}$ in liquid samples (ie, melt streams from ice cores), and the approach has since been applied in a number of studies measuring $\mathrm{rBC}$ concentrations and properties in ice (e.g., [218, 219]), snow [220, 221], lake water [222], and precipitation [223]. Several investigators have also developed more advanced methods for interpreting the scattering measurements made by the SP2 to infer information regarding coatings and/or other particles mixed with $\mathrm{rBC}$ in individual particles [215, 224-226]. These analyses have enabled a number of investigations into atmospheric processing of $\mathrm{rBC}$ and the role coatings have on $\mathrm{rBC}$ optical properties (e.g., [227]) and hygroscopicity [228, 229].

Uncertainties for pulsed LII measurement methods stem mainly from the need to model the physical behavior of the measured $\mathrm{rBC}$ in order to interpret LII signals and determine
Fig. 9 Schematic of the SP2 optical head from Schwarz et al. [95]

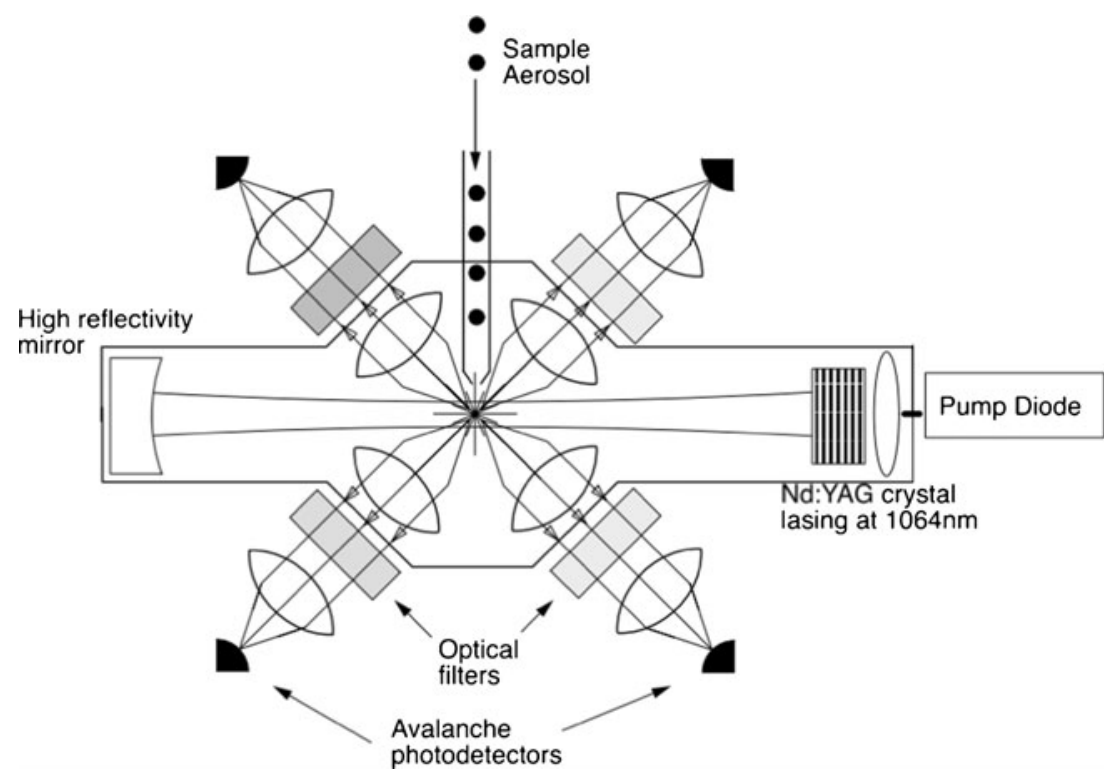


volume concentrations and size distributions [230]. At high laser intensities, $\mathrm{rBC}$ particles vaporize and can undergo restructuring [231], which alters their optical properties and LII signals. Other factors include changes in rBC absorption and extinction properties at different temperatures, expansion of particles as they heat, changes in their refractive index that affect the interpretation of LII signals, and mechanisms through which particles interact with the carrier gas [230]. Measurements of the primary particle size depend on the carrier gas properties and structure of the $\mathrm{rBC}$ aggregates. If the aggregate collapses, some primary particles are shielded from the surrounding air, which affects the aggregate cooling rate and subsequent LII signal decay, leading to a larger inferred primary particle size. Chan et al. [211] used this behavior as a diagnostic for rBC aggregate collapse in atmospheric measurements. The majority of pulsed LII studies have focused on combustion environments where coatings on $\mathrm{rBC}$ particles are relatively minor. For atmospheric applications aged $\mathrm{rBC}$ particles can acquire substantial coatings (e.g., $[56,95])$. At high laser intensities, these coatings will evaporate and should not affect measurement of the volume fraction [211]. If coatings or mixed particles survive the initial particle heating, they might affect the determination of the primary particle size from the observed LII signal decay, as they will affect the cooling rate of the mixed particle.

For continuous LII measurements, several studies have investigated the response of the SP2 to different $\mathrm{rBC}$ calibration standards, ambient $\mathrm{rBC}, \mathrm{rBC}$ mixed with other material, and $\mathrm{rBC}$ with different morphologies [95, 102, 149, 232-234]. These works have shown that the radiation emitted by $\mathrm{rBC}$ particles at their vaporization temperatures is linearly proportional to $\mathrm{rBC}$ mass and independent of mixing state and morphology over a wide range of conditions. The lower particle size threshold for the SP2 is limited by the requirement that particles must be heated to their vaporization temperature, and has been found to be $0.7 \mathrm{fg}(90 \mathrm{~nm}$ volume equivalent diameter) for reasonable laser intensities [235]. The upper size limit of the SP2 is largely governed by the amplification settings on the SP2 thermal emission detectors and the sampling efficiency of large particles to the SP2 detection region. Schwarz et al. [220] have shown that the SP2, when optimized for large particle detection, can adequately measure $\mathrm{rBC}$ up to volume equivalent diameters of $2 \mu \mathrm{m}$. In most ambient environments, the amount of $\mathrm{rBC}$ mass falling outside the SP2 detection range is assumed to be small (10\%-20\%); however, care should be taken when interpreting measurements of fresh emissions where the $\mathrm{rBC}$ size distribution may shift to smaller sizes or when examining number distributions where smaller particles make a more significant contribution to total number concentrations compared with total mass. At high particle concentrations, multiple particles can be present in the sensing volume, so care should be taken to avoid interpreting coincident LII signals as originating from a single, larger particle [236].
The choice of calibration material also affects uncertainties in SP2 LII measurements. Different effective densities and emissivities have been found for atmospheric $\mathrm{rBC}$ calibration materials, which translate to different LII signals for fixed amounts of rBC mass. Moteki and Kondo [197] showed that combining the SP2 with an independent particle mass measurement downstream of a heated inlet system allowed direct comparison of the LII signal and $\mathrm{rBC}$ mass. This work and follow-up studies [234] have shown that $\mathrm{rBC}$ in urban environments has an LII response closest to fullerene soot and that the SP2 response to different calibration materials can be related to ambient $\mathrm{rBC}$ response using empirical corrections. Similar measurements are needed in non-urban environments to verify that relationships hold for all forms of atmospheric rBC.

Additional uncertainties arise when interpreting continuous LII measurements of $\mathrm{rBC}$ present in liquid samples; however, these lie outside the scope of this review. Schwarz et al. [220] is a good starting point for readers interested in more details on uncertainties associated with these methods. Although the identification of coatings associated with $\mathrm{rBC}$ also has significant uncertainties, these are not strictly related to the measurement of rBC mass, so we do not include them here. Readers interested in more details are encouraged to consult the original references [215, 224-226].

There are several differences between pulsed and continuous LII methods that we summarize briefly here. Pulsed LII measurements represent the average properties of an ensemble of $\mathrm{rBC}$-containing particles in the sample volume. Particles are illuminated by intense laser light on the order of nanoseconds. The measured parameters are the $\mathrm{rBC}$ volume fraction and primary particle size. Two-dimensional LII systems also provide qualitative information on the distribution of $\mathrm{rBC}$ within the measurement volume. The technique has mainly been applied to combustion environments, though it is now seeing increasing use in atmospheric applications. The continuous LII method illuminates individual particles on the order of microseconds. The particle mass is determined from the peak LII signal measured when the particle reaches its vaporization temperature. Simultaneous light scattering measurements are used to infer particle-coating properties, whereas measurements of the LII signal over different wavelength ranges are used to infer particle composition. The technique has been used primarily for atmospheric measurements of $\mathrm{rBC}$ but is being extended to measure $\mathrm{rBC}$ in liquids. Both pulsed and continuous LII methods have uncertainties related to the absorption and emission properties of $\mathrm{rBC}$, particularly when it is heated to high temperatures. It is difficult, however, to extrapolate uncertainties from the two different methods because of differences in how the LII signals are measured and interpreted. That said, we are unaware of any studies that have compared measurements from the two approaches, and much could be learned about both techniques by such a comparison. 
A recently developed technique related to LII takes advantage of the selective vaporization that occurs when measuring rBC-containing particle composition using a mass spectrometer. The aerodyne soot particle aerosol mass spectrometer (SP-AMS) is a development of the traditional AMS [237] that replaces the particle vaporization source, a heated metal surface, with the same continuous laser system used in the SP2 [238]. The SP-AMS is not a traditional LII measurement in that the light emitted by the process is not measured. Instead, ions generated from the vapors produced by the LII process are measured to provide detailed chemical information related to both the $\mathrm{rBC}$ and any associated coatings. The technique has already been used to investigate atmospheric $\mathrm{rBC}[56$, 238]. A detailed discussion of the uncertainties associated with this technique are beyond the scope of this review, but interested readers should consult Onasch et al. [238] for a detailed discussion of the technique. The general features of laser-induced incandescence measurement techniques are listed in Table 8.

\section{Morphology of atmospheric EC}

Freshly combusted BC particles are emitted as sub-micron sized aggregates of coagulated spherical primary particles (monomers; see Fig. 10) from high-temperature combustion systems $[46,239,240]$. These monomers can lead to varied morphology that $\mathrm{BC}$ aggregates can assume in the atmosphere and can significantly affect their physical, chemical, and optical properties. Therefore, experimental techniques to characterize their morphology are of prime interest to researchers.

Transmission electron microscopy (TEM) has revealed the structure of these monomers as containing onion-like layers of graphitic platelets [241,242], which are not parallel as in pure, single-crystal graphite, but disordered and wrinkled [11]. In the past four decades, laboratory investigations and computer simulation studies have shown that formation of $\mathrm{BC}$ in combustion systems proceeds via a

Table 8 Laser-induced incandescence technique summary

\begin{tabular}{ll}
\hline Measures & rBC \\
\hline Units & Mass concentration \\
Collection media & None - in situ \\
Collection time & Milliseconds to seconds \\
Uncertainty & $5 \%-10 \%$ \\
Calibration & Commercially available light absorbing \\
& particles. Fullerene for the SP2 \\
Biases & In the SP2, underestimation of rBC mass if \\
& significant mass is in particles smaller or \\
& larger than lower or upper size threshold. \\
Measures BrC & No \\
\hline
\end{tabular}

three-dimensional diffusion-limited cluster aggregation (DLCA) growth mechanism [243-245]), giving rise to their non-Euclidean particle geometry. Since the application of fractal mathematics to the area of condensed matter physics by Forrest and Witten [246], the morphology of EC aggregates has been described using a quantifiable mathematical parameter, the fractal dimension, $D_{f}$. Estimation of this parameter leverages from the fact that within a certain length scale, EC aggregates are scale-invariant, that is, their irregularity is similar between the limits of monomer and aggregate size. Mathematically, the number of monomers per aggregate, $N$, scales with the radius of gyration, $R_{g}$ as [247]:

$N=k_{0}\left(R_{g} / d_{p}\right)^{D_{f}}$

where $k_{0}$ is the fractal pre-factor and $d_{p}$ is the average monomer diameter. The aggregate's $D_{f}$ is considered to be the key property in influencing its physical, chemical, and optical properties.

Past simulation and theoretical investigations have shown that the process of DLCA always yields an asymptotically converging $D_{f}$ value of 1.8 [247-249]. However, one often finds the $D_{f}$ of atmospheric BC aggregates significantly deviating from this value. Freshly emitted $\mathrm{BC}$ aggregates often undergo atmospheric processing, resulting in morphologic restructuring $[55,136]$. Consequently, these aggregates assume sphere-like, collapsed morphologies with a much higher $D_{f}$ (close to three).

Practical methods most commonly used for determination of aggregate morphologic properties are in situ light scattering measurements, characterization, and combination of different physical diameters, and quantitative analysis of digitized ex situ transmission/scanning electron microscopy (TEM/SEM) two-dimensional images [135, 239, 240, 247, 250]. In situ measurement of $D_{f}$ and size of aggregates from angular light scattering measurements involve analysis of scattered light intensity from an ensemble of aggregates in $q$ (or inverse length) space [247]. The slope of the linear regions in the intensity versus $q$ plots is analyzed to calculate the average $D_{f}$ of aggregates. The main limitation of this in situ technique is that when using this method it becomes too complicated for extracting the accurate structural properties for polydisperse aggregate size distributions. Furthermore, the instrumentation required for this measurement methodology is often not portable to active combustion sites, making it difficult to study real-world aerosol particles.

Ex situ techniques involving image analysis of aggregates have found wide use in determining $D_{f}$ of aggregates collected from both laboratory and field studies [135, 239, 251-253]. The Ensemble method (EM) is one of the more popular aggregate morphology characterization techniques used by researchers 
Fig. 10 Scanning (A) and transmission (B) electron microscope images of typical elemental carbon aggregates emitted from high-temperature combustion systems such as engines and biomass burning
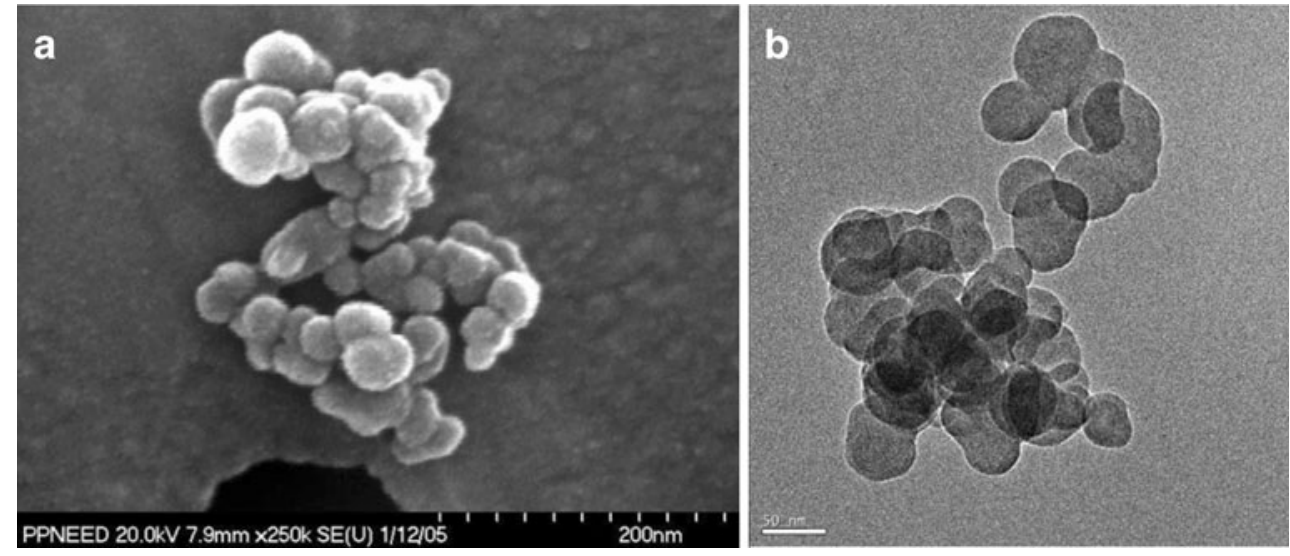

[239, 253-255]. This technique involves determining the values of $N, R_{g}, d_{p}$ from aggregate images, and then using Eq. 1 to determine the $D_{f}$ of aggregates. The main drawback associated with this technique is the difficulty of obtaining accurate three-dimensional information about aggregate morphologic variables such as $N$ and $R_{g}$ required for calculating the three-dimensional $D_{f}$ of aggregates. Although these variables are not directly deducible from a two-dimensional image of an aggregate, empirical relationships between measurable two-dimensional and threedimensional properties of aggregates have been derived from simulation and experimental studies to remedy this situation and assist researchers in their analyses [256-264].

Over the past three decades, researchers have also employed more simplistic image analysis routines such as the nested squares method (NSM) and the perimeter method (PM), which directly determine the $D_{f}$ of aggregates from their two-dimensional images. These techniques do not use the relationship between different aggregate properties of Eq. 1 to determine aggregate $D_{f}$. Determining $D_{f}$ with the NSM technique involves drawing boundaries (e.g., squares or circles) of increasing size upon a two-dimensional, pixilated image of a fractal aggregate centered on the aggregate center of mass $[252,255]$. For every boundary, the number of pixels occupied by the particle is counted. The $D_{f}$ is calculated as the linear regression slope of the linear portion of the log-log curve generated by plotting boundary size against pixel count. The PM calculates $D_{f}$ by drawing grids of differing box sizes upon a two-dimensional image of a fractal aggregate [255, 265]. Given a grid with a certain box size, the number of grid boxes through which the perimeter passes is counted. A grid with a different box size is then drawn, and the number of grid boxes through which the perimeter passes is counted once again. This process is repeated, and the logarithm of the box size is plotted against the logarithm of the box count, providing the $D_{f}$ as the slope.

It is noteworthy to mention that researchers using NSM and PM oftentimes assume that the fractality of the aggregates is conserved between two- and three-dimensions within the aggregate length scale. In other words, the assumption is that the calculated two-dimensional $D_{f}$ equals the threedimensional $D_{f}$. Regarding this assumption, a number of studies $[255,261,264,266]$ have cautioned that factors like orientation of aggregates in the image, location of their center of mass, and the distribution of the primary particles around the center of mass could cause systematic differences between the three-dimensional $D_{f}$ and the two-dimensional $D_{f}$ determined from a two-dimensional projection of the threedimensional structure. Two studies [261, 264] have shown, using computer simulations, that compared to a suspended aggregate, the projected area and length can be overestimated in the two-dimensional projection depending on the resting position of the aggregate on the microscopy filter substrate. More recently, Chakrabarty and coworkers [255] individually tested the accuracies of EM, NSM, and PM in predicting three-dimensional $D_{f}$ of two-dimensional aggregate images by applying them to a statistically significant $(\sim 2500)$ number of projected images of all stable orientations of computer-generated three-dimensional fractal aggregates with $D_{f}$ ranging between 1.0 and 3.0. Their results showed that of the three methods, the only method that can be

Table 9 Morphology technique summary

\begin{tabular}{ll}
\hline Measures & BC structure, fractal dimension \\
\hline Units & $\begin{array}{l}\text { Fractal dimension } \\
\text { Collection media }\end{array}$ \\
electron microscopy grids \\
Collection time & $\begin{array}{l}\text { Minutes to hours } \\
\text { Large uncertainties for nested square and } \\
\text { encertainty }\end{array}$ \\
& ensemble method \\
Calibration & None \\
Biases & Organic carbon coating on BC monomers \\
Measures BrC & No
\end{tabular}


used to reliably determine $D_{f}$ from two-dimensional images is the EM. Both the NSM and the PM yielded many overlapping values of two-dimensional $D_{f}$ for differing values of three-dimensional $D_{f}$ resulting in a non-one-toone relationship and large margins of error. The general features of morphologic measurement techniques are listed in Table 9.

\section{Summary}

Recent attention paid to the climate and health effects of atmospheric black carbon (BC) $[8,267]$ have led to detailed discussions on the general and technical definitions of $\mathrm{BC}$ and the terminology of $\mathrm{BC}$ derived from various measurement methods. Decades of research and a fundamental complexity in the physical, chemical, and optical properties of BC have led to a variety of ill-defined or confusing terminology and a variety of measurement methods. Bond et al. [8] and Petzold et al. [6] provide general definitions and four fundamental physical property definitions of BC. Petzold et al. [6] further define the terminology of the products of various measurement methods that utilize the physical properties of BC listed above.

In this paper, we have reviewed the measurement methods that correspond to the terminology descriptions of Petzold et al. [6]. Basic measurement principles, advantages, disadvantages, uncertainties, and references for further reading are described. Measurements of the mass of elemental carbon (EC) using the combustion properties of the material, the $\mathrm{SP}^{2}$ bonded carbon, insolubility, and the fundamental morphologic properties are discussed. Measurements of the mass of equivalent $\mathrm{BC}(e B C)$ using the fundamental property of light absorption are provided (filter-based absorption), (photo-acoustic absorption), and (photo-thermal interferometry). A review of the measurement of aerosol light absorption using remote sensing, which requires further scientific advances to derive $\mathrm{eBC}$ is provided. Measurements of the mass of refractory $\mathrm{BC}(r B C)$ using the fundamental vaporization properties are described (laser induced incandescence).

The information that has been put forth in this review was compiled with the goal of helping students, engineers, and researchers in many fields to become better oriented to the many facets of black carbon and to expand their knowledge base of the many techniques that are currently employed to measure these facets.

Acknowledgments D.A.L. is funded through the NOAA Climate Program Office. The work of H.M. and R.C. has been supported by NASA EPSCoR under Cooperative Agreement no. NNX10AR89A, NASA ROSES under grant no. NNX11AB79G, the National Science Foundation under grant no. AGS-1040046, and the US Department of Energy Atmospheric System Research program.
Open Access This article is distributed under the terms of the Creative Commons Attribution License which permits any use, distribution, and reproduction in any medium, provided the original author(s) and the source are credited.

\section{References}

1. DeMott PJ, Petters MD, Prenni AJ, Carrico CM, Kreidenweis SM, Collett JL, Moosmuller H (2009) Ice nucleation behavior of biomass combustion particles at cirrus temperatures. J Geophys Res 114 (D16205):doi:10.1029/2009JD012036

2. Petters MD, Parsons MT, Prenni AJ, DeMott PJ, Kreidenweis SM, Carrico CM, Sullivan AP, McMeeking GR, Levin E, Wold CE, Collett JL, Moosmüller H (2009) Ice nuclei emissions from biomass burning. J Geophys Res 114 (D07209):doi:10.1029/2008JD011532

3. Albrecht BA (1989) Aerosols, cloud microphysics, and fractional cloudiness. Science 245(4923):1227-1230. doi:10.1126/Science. 245.4923.1227

4. Twomey SA, Piepgrass M, Wolfe TL (1984) An assessment of the impact of pollution on global cloud albedo. Tellus 36B(5):356-366

5. Smith KR, Jerrett M, Anderson HR, Burnett RT, Stone V, Derwent R, Atkinson RW, Cohen A, Shonkoff SB, Krewski D, Pope CA, Thun MJ, Thurston G (2009) Health and climate change 5: public health benefits of strategies to reduce greenhouse-gas emissions: health implications of short-lived greenhouse pollutants. Lancet 374(9707):2091-2103. doi:10.1016/S0140-6736(09)61716-5

6. Petzold A, Ogren JA, Fiebig M, Laj P, Li S-M, Baltensperger U, Holzer-Popp T, Kinne S, Pappalardo G, Sugimoto N, Wehrli C, Wiedensohler A, Zhang X-Y (2013) Recommendations for the interpretation of "black carbon" measurements. Atmos Chem Phys Discuss 13:9485-9517

7. US Environmental Protection Agency (2012) Report to Congress on Black Carbon. EPA-450/R-412-001

8. Bond TC, Doherty SJ, Fahey DW, Forster PM, Berntsen T, DeAngelo BJ, Flanner MG, Ghan S, Kärcher B, Koch D, Kinne S, Kondo Y, Quinn PK, Sarofim MC, Schultz MG, Schulz M, Venkataraman C, Zhang H, Zhang S, Bellouin N, Guttikunda SK, Hopke PK, Jacobson MZ, Kaiser JW, Klimont Z, Lohmann U, Schwarz JP, Shindell D, Storelvmo T, Warren SG, Zender CS (2013) Bounding the role of black carbon in the climate system: a scientific assessment. J Geophys Res 118(11):5380-5552. doi:10. 1002/jgrd.50171

9. Ogren JA, Charlson RJ (1983) Elemental carbon in the atmosphere: cycle and lifetime. Tellus 35B(4):241-254

10. Andreae MO, Gelencsér A (2006) Black carbon or brown carbon? The nature of light-absorbing carbonaceous aerosols. Atmos Chem Phys 6:3131-3148

11. Bond T, Bergstrom R (2006) Light absorption by carbonaceous particles: an investigative review. Aerosol Sci Technol 40(1):27-67

12. Shah JJ, Rau JA (1990) Carbonaceous species methods comparison study: interlaboratory round robin interpretation of result, final report to Research Division California Air Resources Board, Project A832-154. Sacramento, CA 95812

13. Graber ER, Rudich Y (2006) Atmospheric HULIS: how humic-like are they? A comprehensive and critical review. Atmos Chem Phys 6:729-753

14. Pósfai M, Gelencsér A, Simonics R, Arató K, Li J, Hobbs PV, Buseck PR (2004) Atmospheric tar balls: particles from biomass and biofuel burning. J Geophys Res 109 (D06213):DOI:10.1029/ 2003JD004169

15. Eller PM, Cassinelli ME (1996) Elemental Carbon (Diesel Exhaust): Method 5040. In: NIOSH Manual of Analytical Methods, 4th ed. (1st supplement). National Institute for Occupational Safety and Health (NIOSH): Cincinnati, $\mathrm{OH}$ 
16. Birch ME (1998) Analysis of carbonaceous aerosols: interlaboratory comparison. Analyst 123(5):851-857

17. Chow JC, Watson JG, Lowenthal DH, Solomon PA, Magliano KL, Ziman SD, Richards LW (1993) $\mathrm{PM}_{10}$ and $\mathrm{PM}_{2.5}$ compositions in California's San Joaquin Valley. Aerosol Sci Technol 18(2):105-128

18. Chow JC, Watson JG, Pritchett LC, Pierson WR, Frazier CA, Purcell RG (1993) The DRI thermal/optical reflectance carbon analysis system: description, evaluation and applications in US air quality studies. Atmos Environ 27A(8):1185-1201

19. Watson JG, Chow JC, Chen L-WA (2005) Summary of organic and elemental carbon/black carbon analysis methods and intercomparisons. Aerosol Air Qual Res 5(1):65-102

20. Birch ME, Cary RA (1996) elemental carbon-based method for monitoring occupational exposures to particulate diesel exhaust. Aerosol Sci Technol 25(3):221-241

21. Huntzicker JJ, Johnson RL, Shaw JJ, Cary RA (1982) Analysis of organic and elemental carbon in ambient aerosol by a thermaloptical method. In: Wolff GT, Klimisch RL (eds) Particulate carbon: atmospheric life cycle. Plenum Press, New York, pp 79-88

22. Fung K, Chow JC, Watson JG (2002) Evaluation of OC/EC speciation by thermal manganese dioxide oxidation and the IMPROVE Method. J Air Waste Manag Assoc 52(11):1333-1341

23. Subramanian R, Khlystov AY, Robinson AL (2006) Effect of peak inert-mode temperature on elemental carbon measured using thermal-optical analysis. Aerosol Sci Technol 40(10):763-780

24. Baumgardner D, Popovicheva O, Allan J, Bernardoni V, Cao J, Cavalli F, Cozic J, Diapouli E, Eleftheriadis K, Genberg PJ, Gonzalez C, Gysel M, John A, Kirchstetter TW, Kuhlbusch TAJ, Laborde M, Lack D, Müller T, Niessner R, Petzold A, Piazzalunga A, Putaud JP, Schwarz J, Sheridan P, Subramanian R, Swietlicki E, Valli G, Vecchi R, Viana M (2012) Soot reference materials for instrument calibration and intercomparisons: a workshop summary with recommendations. Atmos Meas Tech 5:1869-1887. doi:10. 5194/amt-5-1869-2012

25. Chow JC, Watson JG, Crow D, Lowenthal DH, Merrifield T (2001) Comparison of IMPROVE and NIOSH carbon measurements. Aerosol Sci Technol 34(1):23-34

26. Schmidt MWI, Masiello CA, Skjemstad JO (2003) Final recommendations for reference materials in black carbon analysis. EOS 84(52):582-583

27. Schmidt MWI, Skjemstad JO, Czimczik CI, Glaser B, Prentice KM, Gelinas Y, Kuhlbusch TAJ (2001) Comparative analysis of black carbon in soils. Glob Biogeochem Cycles 15(1):163-167. doi:10. 1029/2000gb001284

28. Schauer JJ, Mader BT, Deminter JT, Heidemann G, Bae MS, Seinfeld JH, Flagan RC, Cary RA, Smith D, Huebert BJ, Bertram T, Howell S, Kline JT, Quinn P, Bates T, Turpin B, Lim HJ, Yu JZ, Yang H, Keywood MD (2003) ACE-Asia intercomparison of a thermal-optical method for the determination of particle-phase organic and elemental carbon. Environ Sci Technol 37(5):993-1001

29. Cavalli F, Viana M, Yttri KE, Genberg J, Putaud JP (2010) Toward a standardized thermal-optical protocol for measuring atmospheric organic and elemental carbon: the EUSAAR protocol. Atmos Meas Tech 3(1):79-89

30. Piazzalunga A, Bernardoni V, Fermo P, Valli G, Vecchi R (2011) Technical note: on the effect of water-soluble compounds removal on EC quantification by TOT analysis in urban aerosol samples. Atmos Chem Phys 11(19):10193-10203. doi:10.5194/Acp-11-10193-2011

31. Novakov T, Corrigan CE (1995) Thermal characterization of biomass smoke particles. Mikrochim Acta 119(1/2):157-166. doi:10. 1007/Bf01244864

32. Boparai P, Lee JY, Bond TC (2008) Revisiting thermal-optical analyses of carbonaceous aerosol using a physical model. Aerosol Sci Technol 42(11):930-948

33. Wang Y, Chung A, Paulson SE (2010) The effect of metal salts on quantification of elemental and organic carbon in diesel exhaust particles using thermal-optical evolved gas analysis. Atmos Chem Phys 10(23):11447-11457. doi:10.5194/Acp-10-11447-2010

34. Yang H, Yu JZ (2002) Uncertainties in charring correction in the analysis of elemental and organic carbon in atmospheric particles by thermal/optical methods. Environ Sci Technol 36(23):5199-5204

35. Conny JM, Klinedinst DB, Wight SA, Paulsen JL (2003) Optimizing thermal-optical methods for measuring atmospheric elemental (black) carbon: a response surface study. Aerosol Sci Technol 37(9):703-723

36. Chow JC, Watson JG, Chen L-WA, Arnott WP, Moosmüller H, Fung K (2004) Equivalence of elemental carbon by thermal/optical reflectance and transmittance with different temperature protocols. Environ Sci Technol 38(16):4414-4422

37. Sadezky A, Muckenhuber H, Grothe H, Niessner R, Pöschl U (2005) Raman microspectroscopy of soot and related carbonaceous materials: spectral analysis and structural information. Carbon 43(8):1731-1742. doi:10.1016/j.carbon.2005.02.018

38. Dresselhaus MS, Dresselhaus G (1982) Light scattering in graphite intercalation compounds (Chapter 2). In: Cardona M, Güntherodt G (eds) Light scattering in solids III : recent results. Springer-Verlag, Berlin, pp 3-57

39. Sze SK, Siddique N, Sloan JJ, Escribano R (2001) Raman spectroscopic characterization of carbonaceous aerosols. Atmos Environ 35(3):561-568

40. Wang Y, Alsmeyer DC, McCreery RL (1990) Raman spectroscopy of carbon materials: structural basis of observed spectra. Chem Mater 2(5):557-563

41. Ivleva NP, McKeon U, Niessner R, Pöschl U (2007) Raman microspectroscopic analysis of size-resolved atmospheric aerosol particle samples collected with an ELPI: soot, humic-like substances, and inorganic compounds. Aerosol Sci Technol 41(7): 655-671

42. Mertes S, Dippel B, Schwarzenböck A (2004) Quantification of graphitic carbon in atmospheric aerosol particles by raman spectroscopy and first application for the determination of mass absorption efficiencies. J Aerosol Sci 35(3):347-361

43. Rosen H, Hansen ADA, Gundel LA, Novakov T (1978) Identification of the optically absorbing component in urban aerosols. Appl Opt 17(24):3859-3861

44. Keller S, Heintzenberg J (1997) Quantification of graphitic carbon on polycarbonate filters by raman spectroscopy. J Aerosol Sci 28(SUPP (1)):S609-S610

45. Petzold A, Schloesser H, Sheridan PJ, Arnott WP, Ogren JA, Virkkula A (2005) Evaluation of multiangle absorption photometry for measuring aerosol light absorption. Aerosol Sci Technol 39(1): $40-51$

46. Moosmüller H, Chakrabarty RK, Arnott WP (2009) Aerosol light absorption and its measurement: a review. J Quant Spectrosc Radiat Transf 110(11):844-878

47. Grosjean D (1975) Solvent extraction and organic carbon determination in atmospheric particulate matter: the organic extractionorganic carbon analyzer (OE-OCA) Technique. Anal Chem 47(6): 797-805

48. El-Zanan HS, Zielinska B, Mazzoleni LR, Hansen DA (2009) Analytical determination of the aerosol organic mass-to-organic carbon ratio. J Air Waste Manag Assoc 59(1):58-69

49. Kirchstetter TW, Novakov T, Hobbs PV (2004) Evidence that the spectral dependence of light absorption by aerosols is affected by organic carbon. J Geophys Res 109 (D21208):DOI:10.1029/ 2004JD004999

50. Appel BR, Colodny P, Weselowski JJ (1976) Analysis of carbonaceous material in southern california atmospheric aerosols. Environ Sci Technol 10(4):359-363

51. Bond TC, Habib G, Bergstrom RW (2006) Limitations in the enhancement of visible light absorption due to mixing state. J Geophys Res 111 (D20211):doi:10.1029/2006JD007315 
52. Jacobson MZ (2001) Strong radiative heating due to the mixing state of black carbon in atmospheric aerosols. Nature 409(6821):695-697

53. Lack DA, Cappa CD, Cross ES, Massoli P, Ahern AT, Davidovits P, Onasch TB (2009) Absorption enhancement of coated absorbing aerosols: validation of the photo-acoustic technique for measuring the enhancement. Aerosol Sci Technol 43(10):1006-1012

54. Schnaiter M, Linke C, Möhler O, Naumann K-H, Saathoff H, Wagner R, Schurath U, Wehner B (2005) Absorption amplification of black carbon internally mixed with secondary organic aerosol. J Geophys Res 110 (D19204):doi:10.1029/2005JD006046

55. Zhang RY, Khalizov AF, Pagels J, Zhang D, Xue HX, McMurry PH (2008) Variability in morphology, hygroscopicity, and optical properties of soot aerosols during atmospheric processing. Proc Natl Acad Sci U S A 105(30):10291-10296

56. Cappa CD, Onasch TB, Massoli P, Worsnop DR, Bates TS, Cross ES, Davidovits P, Hakala J, Hayden KL, Jobson BT, Kolesar KR, Lack DA, Lerner BM, Li S-M, Mellon D, Nuaaman I, Olfert JS, Petäjä T, Quinn PK, Song C, Subramanian R, Williams EJ, Zaveri RA (2012) Radiative absorption enhancements due to the mixing state of atmospheric black carbon. Science 337(6098):1078-1081. doi:10.1126/science. 1223447

57. Knox A, Evans GJ, Brook JR, Yao X, Jeong CH, Godri KJ, Sabaliauskas K, Slowik JG (2009) Mass absorption cross-section of ambient black carbon aerosol in relation to chemical age. Aerosol Sci Technol 43(6):522-532

58. Lack DA, Corbett JJ (2012) Black carbon from ships: a review of the effects of ship speed, fuel quality and exhaust gas scrubbing. Atmos Chem Phys 12(9):3985-4000. doi:10.5194/acp-12-3985-2012

59. Clarke AD, Shinozuka Y, Kapustin VN, Howell S, Huebert B, Doherty S, Anderson T, Covert D, Anderson J, Hua X, Moore II KG, McNaughton C, Carmichael G, Weber R (2004) Size distributions and mixtures of dust and black carbon aerosol in asian outflow: physiochemistry and optical properties. J Geophys Res 109 (D15S09):DOI:10.1029/2003JD004378

60. Russell PB, Bergstrom RW, Shinozuka Y, Clarke AD, DeCarlo PF, Jimenez JL, Livingston JM, Redemann J, Dubovik O, Strawa A (2010) Absorption angstrom exponent in AERONET and related data as an indicator of aerosol composition. Atmos Chem Phys 10(3): $1155-1169$

61. Gyawali M, Arnott WP, Lewis K, Moosmüller H (2009) In situ aerosol optics in Reno, NV, USA during and after the Summer 2008 California wildfires and the influence of absorbing and nonabsorbing organic coatings on spectral light absorption. Atmos Chem Phys 9:8007-8015

62. Lack DA, Langridge JM (2013) On the attribution of light absorption to black and brown carbon using the absorption Ångström exponent. Atmos Chem Phys Discuss 13:15493-15515. doi:10.5194/acpd-1315493-2013

63. Lack DA, Langridge JM, Bahreini R, Cappa CD, Middlebrook AM, Schwarz JP (2012) Brown carbon and internal mixing in biomass burning particles. Proc Natl Acad Sci. doi:10.1073/pnas. 1206575109

64. Kondo Y, Sahu L, Kuwata M, Miyazaki Y, Takegawa N, Moteki N, Imaru J, Han S, Nakayama T, Oanh NTK, Hu M, Kim YJ, Kita K (2009) Stabilization of the mass absorption cross section of black carbon for filter-based absorption photometry by the use of a heated inlet. Aerosol Sci Technol 43(8):741-756

65. Bond TC, Anderson TL, Campbell D (1999) Calibration and intercomparison of filter-based measurements of visible light absorption by aerosols. Aerosol Sci Technol 30(6):582-600

66. Collaud Coen M, Weingartner E, Apituley A, Ceburnis D, FierzSchmidhauser R, Flentje H, Henzing JS, Jennings SG, Moerman M, Petzold A, Schmid O, Baltensperger U (2010) Minimizing light absorption measurement artifacts of the aethalometer: evaluation of five correction algorithms. Atmos Meas Tech 3(2):457-474. doi:10. 5194/amt-3-457-2010
67. Hansen ADA, Rosen H, Novakov T (1984) The aethalometer-an instrument for the real-time measurement of optical absorption by aerosol particles. Sci Total Environ 36:191-196

68. Lin CI, Baker MB, Charlson RJ (1973) Absorption coefficient of atmospheric aerosols: a method for measurement. Appl Opt 12(6): 1356-1363

69. Petzold A, Schönlinner M (2004) Multi-angle absorption photometry - a new method for the measurement of aerosol light absorption and atmospheric black carbon. J Aerosol Sci 35(4):421-441

70. Virkkula A, Ahlquist NC, Covert DS, Arnott WP, Sheridan PJ, Quinn PK, Coffman DJ (2005) Modification, calibration, and a field test of an instrument for measuring light absorption by particles. Aerosol Sci Technol 39(1):68-83

71. Weingartner E, Saathoff H, Schnaiter M, Streit N, Bitnar B, Baltensperger U (2003) Absorption of light by soot particles: determination of the absorption coefficient by means of aethalometers. J Aerosol Sci 34(10): 1445-1463

72. Lindberg JD, Douglass RE, Garvey DM (1999) Atmospheric particulate absorption and black carbon measurement. Appl Opt 38(12):2369-2376

73. Liousse C, Cachier H, Jennings SG (1993) Optical and thermal measurements of black carbon aerosol content in different environments: variation of the specific attenuation cross-section, Sigma $(\sigma)$. Atmos Environ 27A(8):1203-1211

74. Ballach J, Hitzenberger R, Schultz E, Jaeschke W (2001) Development of an improved optical transmission technique for black carbon (BC) analysis. Atmos Environ 35(12):2089-2100

75. Bodhaine BA (1995) Aerosol absorption measurements at Barrow, Mauna Loa, and the South Pole. J Geophys Res 100(D5):8967-8975

76. LaRosa LE, Buckley TJ, Wallace LA (2002) Real-time indoor and outdoor measurements of black carbon in an occupied house: an examination of sources. J Air Waste Manag Assoc 52(1):41-49

77. Lindberg JD, Douglass RE, Garvey DM (1993) Carbon and the optical properties of atmospheric dust. Appl Opt 32(30):6077-6081

78. Petzold A, Kopp C, Niessner R (1997) The dependence of the specific attenuation cross-section on black carbon mass fraction and particle size. Atmos Environ 31(5):661-672

79. Saathoff H, Naumann K-H, Schnaiter M, Schöck W, Weingartner E, Baltensperger U, Krämer L, Bozoki Z, Pöschl U, Niessner R, Schurath U (2003) Carbon mass determinations during the AIDA soot aerosol campaign 1999. J Aerosol Sci 34(10):1399-1420

80. Cappa C, Lack D, Burkholder J, Ravishankara AR (2008) Bias in filter-based aerosol light absorption measurements due to organic aerosol loading: evidence from laboratory measurements. Aerosol Sci Technol 42(12):1022-1032

81. Lack D, Cappa C, Covert D, Baynard T, Massoli P, Sierau B, Bates T, Quinn P, Lovejoy E, Ravishankara AR (2008) Bias in filter-based aerosol light absorption measurements due to organic aerosol loading: evidence from ambient measurements. Aerosol Sci Technol 42(12):1033-1041

82. Subramanian R, Roden CA, Boparai P, Bond TC (2007) Yellow beads and missing particles: trouble ahead for filter-based absorption measurements. Aerosol Sci Technol 41(6):630-637

83. Schmid O, Artaxo P, Arnott WP, Chand D, Gatti LV, Frank GP, Hoffer A, Schnaiter M, Andreae MO (2006) Spectral light absorption by ambient aerosols influenced by biomass burning in the amazon basin. I: comparison and field calibration of absorption measurement techniques. Atmos Chem Phys 6:3443-3462

84. Clarke AD (1982) Integrating sandwich: a new method of measurement of the light absorption coefficient for atmospheric particles. Appl Opt 21(16):3011-3020

85. Clarke AD, Noone KJ, Heintzenberg J, Warren SG, Covert DS (1987) Aerosol light absorption measurement techniques: analysis and intercomparison. Atmos Environ 21(6):1455-1465

86. Heintzenberg J, Charlson RJ, Clarke AD, Liousse C, Ramaswamy V, Shine KP, Wendisch M, Helas G (1997) Measurements and 
modelling of aerosol single-scattering albedo: progress, problems, and prospects. Beiträge zur Physik der Atmosphäre 70(4):249-263

87. Horvath H (1997) Experimental Calibration for aerosol light absorption measurements using the integrating plate method-summary of the data. J Aerosol Sci 28(7):1149-1161

88. Reid JS, Hobbs PV, Liousse C, Martins JV, Weiss RE, Eck TF (1998) Comparisons of techniques for measuring shortwave absorption and black carbon content of aerosols from biomass burning in Brazil. J Geophys Res 103(D24):32031-32040

89. Miyazaki Y, Kondo Y, Sahu LK, Imaru J, Fukushima N, Kano M (2008) Performance of a newly designed continuous soot monitoring system (COSMOS). J Environ Monit 10(10):1195-1201. doi:10.1039/ b806957c

90. Krecl P, Ström J, Johansson C (2007) Carbon content of atmospheric aerosols in a residential area during the wood combustion season in Sweden. Atmos Environ 41(33):6974-6985. doi:10.1016/j. atmosenv.2007.06.025

91. Müller T, Schladitz A, Massling A, Kaaden N, Kandler K, Wiedensohler A (2009) Spectral absorption coefficients and imaginary parts of refractive indices of saharan dust during SAMUM-1. Tellus 61B(1):79-95

92. Arnott WP, Hamasha K, Moosmüller H, Sheridan PJ, Ogren JA (2005) Towards aerosol light-absorption measurements with a 7wavelength aethalometer: evaluation with a photoacoustic instrument and 3-wavelength nephelometer. Aerosol Sci Technol 39(1):17-29

93. Ogren JA (2010) Comment on on "Calibration and Intercomparison of Filter-Based Measurements of Visible Light Absorption by Aerosols". Aerosol Sci Technol 44(8):589-591

94. Virkkula A (2010) Correction of the calibration of the 3-wavelength particle soot absorption photometer (3 PSAP). Aerosol Sci Technol 44(8):706-712

95. Schwarz JP, Gao RS, Fahey DW, Thomson DS, Watts LA, Wilson JC, Reeves JM, Darbeheshti M, Baumgardner DG, Kok GL, Chung SH, Schulz M, Hendricks J, Lauer A, Kärcher B, Slowik JG, Rosenlof KH, Thompson TL, Langford AO, Loewenstein M, Aikin KC (2006) Single-particle measurements of midlatitude black carbon and lightscattering aerosols from the boundary layer to the lower stratosphere. J Geophys Res 111 (D16207):doi:10.1029/2006JD007076

96. Lack DA, Lovejoy ER, Baynard T, Pettersson A, Ravishankara AR (2006) Aerosol absorption measurement using photoacoustic spectroscopy: sensitivity, calibration, and uncertainty developments. Aerosol Sci Technol 40(9):697-708

97. Sheridan PJ, Arnott WP, Ogren JA, Andrews E, Atkinson DB, Covert DS, Moosmüller H, Petzold A, Schmidt B, Strawa AW, Varma R, Virkkula A (2005) The Reno aerosol optics study: an evaluation of aerosol absorption measurement methods. Aerosol Sci Technol 39(1):1-16

98. Lack DA, Corbett JJ, Onasch T, Lerner B, Massoli P, Quinn PK, Bates TS, Covert DS, Coffman D, Sierau B, Herndon S, Allan J, Baynard T, Lovejoy E, Ravishankara AR, Williams E (2009) Particulate emissions from commercial shipping: chemical, physical, and optical properties. J Geophys Res 114 (D00F04):doi:10. 1029/2008JD011300

99. Park K, Chow JC, Watson JG, Trimble DL, Doraiswamy P, Park K, Arnott WP, Stroud KR, Bowers K, Bode R, Petzold A, Hansen ADA (2006) Comparison of continuous and filter-based carbon measurements at the Fresno supersite. J Air Waste Manag Assoc 56(4):474-491

100. Rice J (2004) Comparison of integrated filter and automated carbon aerosol measurements at Research Triangle Park, North Carolina. Aerosol Sci Technol 38(S2):23-36

101. Schnaiter M, Schmid O, Petzold A, Fritzsche L, Klein KF, Andreae MO, Helas G, Thielmann A, Gimmler M, Möhler O, Linke C, Schurath U (2005) Measurement of wavelength-resolved light absorption by aerosols utilizing a UV-VIS extinction cell. Aerosol Sci Technol 39(3):249-260
102. Slowik JG, Cross ES, Han J-H, Davidovits P, Onasch TB, Jayne JT, Williams LR, Canagaratna MR, Worsnop DR, Chakrabarty RK, Moosmüller H, Arnott WP, Schwarz JP, Gao R-S, Fahey DW, Kok GL, Petzold A (2007) An inter-comparison of instruments measuring black carbon content of soot particles. Aerosol Sci Technol 41(3):295-314

103. Wallace L (2005) Real-time measurements of black carbon indoors and outdoors: a comparison of the photoelectric aerosol sensor and the aethalometer. Aerosol Sci Technol 39(10):1015-1025. doi:10.1080 02786820500365363

104. Northrop WF, Bohac SV, Chin J-Y, Assanis DN (2011) Comparison of filter smoke number and elemental carbon mass from partially premixed low temperature combustion in a direct-injection diesel engine. J Eng Gas Turbines Power 133(10):102804-102806. doi: $10.1115 / 1.4002918$

105. Tam AC (1986) Applications of photoacoustic sensing techniques. Rev Mod Phys 58(2):381-431

106. Arnott WP, Moosmüller H, Walker JW (2000) Nitrogen dioxide and kerosene-flame soot calibration of photoacoustic instruments for measurement of light absorption by aerosols. Rev Sci Instrum 71(7):4545-4552

107. Tian G, Moosmüller H, Arnott WP (2009) Simultaneous photoacoustic spectroscopy of aerosol and oxygen A-band absorption for the calibration of aerosol light absorption measurements. Aerosol Sci Technol 43(11):1084-1090

108. Gillis KA, Havey DK, Hodges JT (2010) Standard photoacoustic spectrometer: model and validation using $\mathrm{O}_{2}$ A-band spectra. Rev Sci Instrum 81(6):064902

109. Abu-Rahmah A, Arnott WP, Moosmüller H (2006) Integrating nephelometer with a low truncation angle and an extended calibration scheme. Meas Sci Technol 17(7):1723-1732

110. Arnott WP, Zielinska B, Rogers CF, Sagebiel J, Park K, Chow J, Moosmüller H, Watson JG, Kelly K, Wagner D, Sarofim A, Lighty J, Palmer G (2005) Evaluation of 1047-nm photoacoustic instruments and photoelectric aerosol sensors in source-sampling of black carbon aerosol and particle-bound PAHs from gasoline- and dieselpowered vehicles. Environ Sci Technol 39(14):5398-5406

111. Adams KM, Davis LI Jr, Japar SM, Finley DR, Cary RA (1990) Measurement of atmospheric elemental carbon: real-time data for Los Angeles during summer 1987. Atmos Environ 24A(3):597604

112. Tian G, Moosmüller H, Arnott WP (2013) Influence of photolysis on multispectral photoacoustic measurement of nitrogen dioxide concentration. J Air Waste Manag Assoc 63(9):1091-1097

113. Arnott WP, Moosmüller H, Sheridan PJ, Ogren JA, Raspet R, Slaton WV, Hand JL, Kreidenweis SM, Collett JL Jr (2003) Photoacoustic and filter-based ambient aerosol light absorption measurements: instrument comparison and the role of relative humidity. J Geophys Res 108(D1):4034-4044. doi:10.1029/2002JD002165

114. Raspet R, Slaton WV, Arnott WP, Moosmüller H (2003) Evaporation-condensation effects on resonant photoacoustics of volatile aerosols. J Atmos Ocean Technol 20(5):685-695

115. Langridge JM, Richardson MS, Lack D, Law D, Murphy DM (2011) Aircraft instrument for comprehensive characterization of aerosol optical properties, part I: Wavelength-dependent optical extinction and its relative humidity dependence measured using cavity ringdown spectroscopy. Aerosol Sci Technol 45:(11)13051318. doi:10.1080/02786826.2011.592745

116. Murphy DM (2009) The effect of water evaporation on photoacoustic signals in transition and molecular flow. Aerosol Sci Technol 43(4):356-363

117. Chan $\mathrm{CH}$ (1975) Effective absorption for thermal blooming due to aerosols. Appl Phys Lett 26(11):628-630

118. Arnott WP, Moosmüller H, Rogers CF, Jin T, Bruch R (1999) Photoacoustic spectrometer for measuring light absorption by aerosol: instrument description. Atmos Environ 33(17):2845-2852 
119. Adams KM, Davis LI Jr, Japar SM, Finley DR (1990) Real-time, in situ measurement of atmospheric optical absorption in the visible via photoacoustic spectroscopy-IV. Visibility degradation and aerosol optical properties in Los Angeles. Atmos Environ 24A(3):605-610

120. Petzold A, Niessner R (1995) Novel design of a resonant photoacoustic spectrophone for elemental carbon mass monitoring. Appl Phys Lett 66(10):1285-1287

121. Petzold A, Niessner R (1996) Photoacoustic soot sensor for in-situ black carbon monitoring. Appl Phys B 63(2):191-197

122. Gerlach R, Amer NM (1980) Brewster window and windowless resonant spectrophones for intracavity operation. Appl Phys 23(3): 319-326

123. Adams KM (1988) Real-time in situ measurements of atmospheric optical absorption in the visible via photoacoustic spectroscopy. 1: evaluation of photoacoustic cells. Appl Opt 27(19):4052-4056

124. Lewis K, Arnott WP, Moosmüller H, Wold CE (2008) Strong spectral variation of biomass smoke light absorption and single scattering albedo observed with a novel dual-wavelength photoacoustic instrument. J Geophys Res 113 (D16203):doi:10.1029/ 2007JD009699

125. Sharma N, Arnold IJ, Moosmüller H, Arnotl WP, Mazzoleni C (2013) Photoacoustic and nephelometric spectroscopy of aerosol optical properties with a supercontinuum light source. Atmos Meas Tech Discuss 6:6293-6327

126. Ajtai T, Filep Á, Schnaiter M, Linke C, Vragel M, Bozóki Z, Szabó G, Leisner T (2010) A novel multi-wavelength photoacoustic spectrometer for the measurement of the UV-Vis-NIR spectral absorption coefficient of atmospheric aerosols. J Aerosol Sci 41(11):1020 1029. doi:10.1016/j.jaerosci.2010.07.008

127. Haisch C, Menzenbach P, Bladt H, Niessner R (2012) A wide spectral range photoacoustic aerosol absorption spectrometer. Anal Chem 84:8941-8945. doi:10.1021/ac302194u

128. Lack DA, Richardson MS, Law D, Langridge JM, Cappa CD, McLaughlin RJ, Murphy DM (2012) Aircraft instrument for comprehensive characterization of aerosol optical properties, Part 2: black and brown carbon absorption and absorption enhancement measured with photo acoustic spectroscopy. Aerosol Sci Technol 46(5):555-568

129. Chakrabarty RK, Moosmüller H, Chen L-WA, Lewis K, Arnott WP, Mazzoleni C, Dubey MK, Wold CE, Hao WM, Kreidenweis SM (2010) Brown carbon in tar balls from smoldering biomass combustion. Atmos Chem Phys 10:6363-6370

130. Lack DA, Bahreini R, Langridge JM, Gilman JB, Middlebrook AM (2013) Brown carbon absorption linked to organic mass tracers in biomass burning particles. Atmos Chem Phys 13(5):2415-2422. doi:10.5194/Acp-13-2415-2013

131. Chakrabarty RK, Arnold IJ, Francisco DM, Hatchet B, Hosseinpour F, Loria M, Pokharel A, Woody BM (2013) Black and brown carbon fractal aggregates from combustion of two fuels widely used in Asian rituals. J Quant Spectrosc Radiat Transf 122:25-30

132. Flowers BA, Dubey MK, Mazzoleni C, Stone EA, Schauer JJ, Kim S-W, Yoon SC (2010) Optical-chemical-microphysical relationships and closure studies for mixed carbonaceous aerosols observed at Jeju Island; 3-laser photoacoustic spectrometer, particle sizing, and filter analysis. Atmos Chem Phys 10(21):10387-10398

133. Moosmüller H, Engelbrecht JP, Skiba M, Frey G, Chakrabarty RK, Arnott WP (2012) Single scattering albedo of fine mineral dust aerosols controlled by iron concentration. J Geophys Res 117 (D11210):doi:10.1029/2011JD016909

134. Lack DA, Cappa CD (2010) Impact of brown and clear carbon on light absorption enhancement, single scatter albedo and absorption wavelength dependence of black carbon. Atmos Chem Phys 10(9): 4207-4220

135. Chakrabarty RK, Moosmüller H, Arnott WP, Garro MA, Slowik JG, Cross ES, Han J-H, Davidovits P, Onasch TB, Worsnop DR (2007) Light scattering and absorption by fractal-like carbonaceous chain aggregates: comparison of theories and experiment. Appl Opt 46(28):6990-7006

136. Lewis K, Arnott WP, Moosmüller H, Chakrabarty RK, Carrico CM, Kreidenweis SM, Day DE, Malm WC, Laskin A, Jimenez JL, Ulbrich IM, Huffman JA, Onasch TB, Trimborn A, Lui L, Mishchenko MI (2009) Reduction in biomass burning aerosol light absorption upon humidification: roles of inorganically-induced hygroscopicity, particle collapse, and photoacoustic heat and mass transfer. Atmos Chem Phys 9:8949-8966

137. Bialkowski SE (1996) Photothermal spectroscopy methods for chemical analysis. In: Winefordner JD (ed) Chemical analysis: a series of monographs on analytical chemistry and its application, vol 134. John Wiley and Sons, New York

138. Davis CC (1980) Trace detection in gases using phase fluctuation optical heterodyne spectroscopy. Appl Phys Lett 36(7):515-518

139. Davis CC, Petuchowski SJ (1981) Phase fluctuation optical heterodyne spectroscopy of gases. Appl Opt 20(14):2539-2554

140. Davis CC, Petuchowski SJ (1981) Phase fluctuation optical heterodyne spectroscopy of gases: errata. Appl Opt 20(24):4151

141. Lin H-B, Campillo AJ (1985) Photothermal aerosol absorption spectroscopy. Appl Opt 24(3):422-433

142. Fluckiger DU, Lin H-B, Marlow WH (1985) Composition measurement of aerosols of submicrometer particles by phase fluctuation absorption spectroscopy. Appl Opt 24(11):1668-1681

143. Sedlacek AJ (2006) Real-time detection of ambient aerosols using photothermal interferometry: folded Jamin interferometer. Rev Sci Instrum 77(6):064903

144. Moosmüller H, Arnott WP, Rogers CF (1997) Methods for real time, in situ measurement of aerosol light absorption. J Air Waste Manag Assoc 47:157-166

145. Sedlacek A, Lee J (2007) Photothermal interferometric aerosol absorption spectrometry. Aerosol Sci Technol 41(12):1089-1101

146. Moosmüller H, Arnott WP (1996) Folded Jamin interferometer: a stable instrument for refractive-index measurements. Opt Lett 21(6): 438-440

147. Owens MA, Davis CC, Dickerson RR (1999) A photothermal interferometer for gas-phase ammonia detection. Anal Chem 71(7):1391-1399. doi:10.1021/ac980810h

148. Dovichi NJ (1990) Laser-based microchemical analysis. Rev Sci Instrum 61(12):3653-3668

149. Cross ES, Onasch TB, Ahern A, Wrobel W, Slowik JG, Olfert J, Lack DA, Massoli P, Cappa CD, Schwarz JP, Spackman JR, Fahey DW, Sedlacek A, Trimborn A, Jayne JT, Freedman A, Williams LR, Ng NL, Mazzoleni C, Dubey M, Brem B, Kok G, Subramanian R, Freitag S, Clarke A, Thornhill D, Marr LC, Kolb CE, Worsnop DR, Davidovits P (2010) Soot particle studiesinstrument inter-comparison-project overview. Aerosol Sci Technol 44(8):592-611

150. Abou-Zeid A, Wiese P (1998) Interferometer with a wavelengthtuned diode laser for surface profilometry. Meas Sci Technol 9(7): $1105-1110$

151. Downs MJ (1990) A proposed design for an optical interferometer with sub-nanometric resolution. Nanotechnology 1(1):27

152. Ishii Y, Chen J, Murata K (1987) Digital phase-measuring interferometry with a tunable laser diode. Opt Lett 12(4):233-235

153. Stone JA, Stejskal A, Howard L (1999) Absolute interferometry with a 670-nm external cavity diode laser. Appl Opt 38(28):59815994

154. Giles DM, Holben BN, Eck TF, Sinyuk A, Smirnov A, Slutsker I, Dickerson RR, Thompson AM, Schafer JS (2012) An analysis of AERONET aerosol absorption properties and classifications representative of aerosol source regions. J Geophys Res 117 (D17203): doi:10.1029/2012JD018127

155. Measures RM (1984) Laser remote sensing: fundamentals and applications. John Wiley \& Sons, Inc., New York

156. Shaw GE (1983) Sun photometry. Bull Am Meteorol Soc 64(1):4-10 
157. Alvarez RJ II, Caldwell LM, Wolyn PG, Krueger DA, McKee TB, She CY (1993) Profiling temperature, pressure, and aerosol properties using a high spectral resolution lidar employing atomic blocking filters. J Atmos Ocean Technol 10(4):546-556

158. Piironen P, Eloranta EW (1994) Demonstration of a high-spectralresolution lidar based on an iodine absorption filter. Opt Lett 19(3): 234-236

159. Esselborn M, Wirth M, Fix A, Tesche M, Ehret G (2008) Airborne high spectral resolution lidar for measuring aerosol extinction and backscatter coefficients. Appl Opt 47(3):346-358

160. Hair JW, Caldwell LM, Krueger DA, She C-Y (2001) Highspectral-resolution lidar with iodine-vapor filters: measurement of atmospheric-state and aerosol profiles. Appl Opt 40(30): 5280-5294

161. Hair JW, Hostetler CA, Cook AL, Harper DB, Ferrare RA, Mack TL, Welch W, Izquierdo LR, Hovis FE (2008) Airborne high spectral resolution lidar for profiling aerosol optical properties. Appl Opt 47(36):6734-6752

162. Whiteman DN (2003) Examination of the traditional raman lidar technique. II. Evaluating the ratios for water vapor and aerosols. Appl Opt 42(15):2593-2608

163. Goldsmith JE, Blair FH, Bisson SE, Turner DD (1998) Turnkey Raman lidar for profiling atmospheric water vapor, clouds, and aerosols. Appl Opt 37(21):4979-4990

164. Moosmüller H, Wilkerson TD (1997) Combined Raman-elastic backscatter lidar method for the measurement of backscatter ratios. Appl Opt 36(21):5144-5147

165. Perrone MR, Barnaba F, Tomasi FD, Gobbi GP, Tafuro AM (2004) Imaginary refractive-index effects on desert-aerosol extinction versus backscatter relationships at $351 \mathrm{~nm}$ : numerical computations and comparison with Raman lidar measurements. Appl Opt 43(29): $5531-5541$

166. Müller D, Wandinger U, Althausen D, Fiebig M (2001) Comprehensive particle characterization from three-wavelength Raman-lidar observations: case study. Appl Opt 40(27):4863-4869

167. Reagan JA, Byrne DM, King MD, Spinhirne JD, Herman BM (1980) Determination of the complex refractive-index and size distribution of atmospheric particulates from bistatic-monostatic lidar and solar radiometer measurements. J Geophys Res 85(C3): 1591-1599

168. Herman B, Browning R, De Luisi J (1975) Determination of the effective imaginary term of the complex refractive index of atmospheric dust by remote sensing: the diffuse-direct radiation method. J Atmos Sci 32(5):918-925

169. Holben BN, Eck TF, Slutsker I, Tanré D, Buis JP, Setzer A, Vermote E, Reagan JA, Kaufman YJ, Nakajima T, Lavenu F, Jankowiak I, Smirnov A (1998) AERONET - a federated instrument network and data archive for aerosol characterization. Remote Sens Environ 66(1):1-16

170. Harrison L, Michalsky J, Berndt J (1994) Automated multifilter rotating shadow-band radiometer: an instrument for optical depth and radiation measurements. Appl Opt 33(22):5118-5125

171. Stokes GM, Schwartz SE (1994) The atmospheric radiation measurement (ARM) program: programmatic background and design of the cloud and radiation test bed. Bull Am Meteorol Soc 75(7):1201-1221

172. Alexandrov MD, Lacis AA, Carlson BE, Cairns B (2002) Remote sensing of atmospheric aerosols and trace gases by means of multifilter rotating shadowband radiometer. Part I: retrieval algorithm. J Atmos Sci 59(3):524-543

173. Taylor TE, L'Ecuyer TS, Slusser JR, Stephens GL, Goering CD (2008) An operational retrieval algorithm for determining aerosol optical properties in the ultraviolet. J Geophys Res 113 (D03201): doi:10.1029/2007JD008661

174. Dubovik O, King MD (2000) A flexible inversion algorithm for retrieval of aerosol optical properties from sun and sky radiance measurements. J Geophys Res 105(D16):20673-20696
175. Dubovik O, Sinyuk A, Lapyonok T, Holben BN, Mishchenko M, Yang P, Eck TF, Volten H, Munoz O, Veihelmann B, van der Zande WJ, Leon JF, Sorokin M, Slutsker I (2006) Application of spheroid models to account for aerosol particle nonsphericity in remote sensing of desert dust. J Geophys Res 111 (D11208):doi:10.1029/ 2005JD006619

176. Derimian Y, Karnieli A, Kaufman YJ, Andreae MO, Andreae TW, Dubovik O, Maenhaut W, Koren I (2008) The role of iron and black carbon in aerosol light absorption. Atmos Chem Phys 8(13):3623-3637

177. Sato M, Hansen J, Koch D, Lacis A, Ruedy R, Dubovik O, Holben B, Chin M, Novakov T (2003) Global atmospheric black carbon inferred from AERONET. Proc Natl Acad Sci U S A 100(11):6319-6324

178. Eck TF, Holben BN, Reid JS, O'Neill NT, Schafer JS, Dubovik O, Smirnov A, Yamasoe MA, Artaxo P (2003) High aerosol optical depth biomass burning events: a comparison of optical properties for different source regions. Geophys Res Lett 30 (20):DOI:10. 1029/2003GLO17861)

179. Kaufman YJ, Tanre D, Gordon HR, Nakajima T, Lenoble J, Frouin R, Grassl H, Herman BM, King MD, Teillet PM (1997) Passive remote sensing of tropospheric aerosol and atmospheric correction for the aerosol effect. J Geophys Res 102(D14):16815-16830

180. Fraser RS, Kaufman YJ (1985) The relative importance of aerosol scattering and absorption in remote sensing. IEEE Trans Geosci Remote Sens GE-23(5):625-633

181. Kaufman YJ (1987) Satellite sensing of aerosol absorption. J Geophys Res 92(D4):4307-4317

182. Kaufman YJ, Martins JV, Remer LA, Schoeberl MR, Yamasoe MA (2002) Satellite retrieval of aerosol absorption over the oceans using sunglint. Geophys Res Lett 29 (19):doi:10.1029/2002GL015403

183. Herman JR, Bhartia PK, Torres O, Hsu C, Seftor C, Celarier E (1997) Global distribution of UV-absorbing aerosols from Nimbus 7/TOMS data. J Geophys Res 102(D14):16911-16922

184. Hsu NC, Herman JR, Gleason JF, Torres O, Seftor CJ (1999) Satellite detection of smoke aerosols over a snow/ice surface by TOMS. Geophys Res Lett 26(8):1165-1168

185. Remer LA, Kaufman YJ, Tanré D, Mattoo S, Chu DA, Martins JV, Li R-R, Ichoku C, Levy RC, Kleidman RG, Eck TF, Vermote E, Holben BN (2005) The MODIS aerosol algorithm, products, and validation. J Atmos Sci 62(4):947-973

186. Torres O, Bhartia PK, Herman JR, Ahmad Z, Gleason J (1998) Derivation of aerosol properties from satellite measurements of backscattered ultraviolet radiation: theoretical basis. J Geophys Res 103(D14):17099-17110

187. Hu RM, Martin RV, Fairlie TD (2007) Global retrieval of columnar aerosol single scattering albedo from space-based observations. J Geophys Res 112 (D02204):doi:10.1029/2005JD006832

188. Jeong M-J, Hsu C (2008) Retrievals of aerosol single-scattering albedo and effective aerosol layer height for biomass-burning smoke: synergy derived from "A-Train" sensors. Geophys Res Lett 35 (L24801):doi:10.1029/2008GL036279

189. Zhu L, Martins JV, Remer LA (2011) Biomass burning aerosol absorption measurements with MODIS using the critical reflectance method. J Geophys Res 116 (D07202):doi:10.1029/2010JD015187

190. Kalashnikova OV, Kahn R, Sokolik IN, Li WH (2005) Ability of multiangle remote sensing observations to identify and distinguish mineral dust types: optical models and retrievals of optically thick plumes. J Geophys Res 110 (D18S14):doi:10.1029/2004JD004550

191. Kalashnikova OV, Kahn R (2006) Ability of multiangle remote sensing observations to identify and distinguish mineral dust types: 2. Sensitivity over dark water. J Geophys Res 111 (D11207):doi:10. 1029/2005JD006756

192. Kalashnikova OV, Kahn R (2008) Mineral dust plume evolution over the atlantic from MISR and MODIS aerosol retrievals. J Geophys Res 113 (D24204):doi:10.1029/2008JD010083

193. Kahn RA, Gaitley BJ, Garay MJ, Diner DJ, Eck TF, Smirnov A, Holben BN (2010) Multiangle imaging spectroradiometer global 
aerosol product assessment by comparison with the aerosol robotic network. J Geophys Res 115 (D23209):doi:10.1029/2010JD014601

194. Mishchenko MI, Cairns B, Kopp G, Schueler CF, Fafaul BA, Hansen JE, Hooker RJ, Itchkawich T, Maring HB, Travis LD (2007) Accurate monitoring of terrestrial aerosols and total solar irradiance - introducing the Glory Mission. Bull Am Meteorol Soc 88(5):677-691

195. Mishchenko MI, Cairns B, Hansen JE, Travis LD, Burg R, Kaufman YJ, Martins JV, Shettle EP (2004) Monitoring of Aerosol forcing of climate from space: analysis of measurement requirements. J Quant Spectrosc Radiat Transf 88(1/3):149-161

196. Chowdhary J, Cairns B, Mishchenko MI, Hobbs PV, Cota GF, Redemann J, Rutledge K, Holben BN, Russell E (2005) Retrieval of aerosol scattering and absorption properties from photopolarimetric observations over the ocean during the CLAMS experiment. J Atmos Sci 62(4):1093-1117

197. Moteki N, Kondo Y (2010) Dependence of laser-induced incandescence on physical properties of black carbon aerosols: measurements and theoretical interpretation. Aerosol Sci Technol 44(8): 663-675

198. Eckbreth AC (1977) Effects of laser-modulated particulate incandescence on Raman scattering diagnostics. J Appl Phys 48(11): 4473-4479

199. Weeks RW, Duley WW (1974) Aerosol-particle sizes from light emission during excitation by TEA $\mathrm{CO}_{2}$ laser pulses. J Appl Phys 45(10):4661-4662

200. Melton LA (1984) Soot diagnostic based on laser heating. Appl Opt 23(13):2201-2208

201. Dasch CJ (1984) Continuous-wave probe laser investigation of laser vaporization of small soot particles in a flame. Appl Opt 23(13): 2209-2215

202. Michelsen HA, Schrader PE, Goulay F (2010) Wavelength and temperature dependences of the absorption and scattering cross sections of soot. Carbon 48:2175-2191

203. Quay B, Lee T-W, Ni T, Santoro RJ (1994) Spatially resolved measurements of soot volume fraction using laser-induced incandescence. Combust Flame 97(3/4):384-392

204. Shaddix CR, Smyth KC (1996) Laser-induced incandescence measurements of soot production in steady and flickering methane, propane, and ethylene diffusion flames. Combust Flame 107(4): 418-452. doi:10.1016/S0010-2180(96)00107-1

205. Mewes B, Seitzman JM (1997) Soot volume fraction and particle size measurements with laser-induced incandescence. Appl Opt 36(3):709-717

206. Rohlfing EA, Chandler DW (1990) Two-color pyrometric imaging of laser-heated carbon particles in a supersonic flow. Chem Phys Lett 170(1):44-50. doi:10.1016/0009-2614(90)87087-8

207. Snelling DR, Link O, Thomson KA, Smallwood GJ (2011) Measurement of soot morphology by integrated lii and elastic light scattering. Appl Phys B 104(2):385-397. doi:10.1007/S00340-0114394-6

208. Case ME, Hofeldt DL (1996) Soot mass concentration measurements in diesel engine exhaust using laser-induced incandescence. Aerosol Sci Technol 25(1):46-60

209. McEwen JDN, Johnson MR (2012) Black carbon particulate matter emission factors for buoyancy-driven associated gas flares. J Air Waste Manag Assoc 62(3):307-321. doi:10.1080/10473289.2011. 650040

210. Ma L, Cao T, Thompson J (2013) Technical note: aeolian dust proxies produce visible luminescence upon intense laserillumination that results from incandescence of internally mixed carbon. Atmos Meas Tech Discuss 6(3):5173-5194

211. Chan TW, Brook JR, Smallwood GJ, Lu G (2011) Time-resolved measurements of black carbon light absorption enhancement in urban and near-urban locations of southern Ontario, Canada. Atmos Chem Phys 11(20):10407-10432
212. Stephens M, Turner N, Sandberg J (2003) Particle identification by laser-induced incandescence in a solid-state laser cavity. Appl Opt 42(19):3726-3736

213. Baumgardner D, Kok G, Raga G (2004) Warming of the arctic lower stratosphere by light absorbing particles. Geophys Res Lett 31 (6):DOI:10.1029/2003GL018883

214. Baumgardner D, Kok G, Raga G (2007) On the diurnal variability of particle properties related to light absorbing carbon in mexico city. Atmos Chem Phys 7(10):2517-2526

215. Moteki N, Kondo Y, Miyazaki Y, Takegawa N, Komazaki Y, Kurata G, Shirai T, Blake DR, Miyakawa T, Koike M (2007) Evolution of mixing state of black carbon particles: aircraft measurements over the western Pacific in March 2004. Geophys Res Lett 34 (L11803): doi:10.1029/2006GL028943

216. Shiraiwa M, Kondo Y, Moteki N, Takegawa N, Miyazaki Y, Blake DR (2007) Evolution of mixing state of black carbon in polluted air from Tokyo. Geophys Res Lett 34 (L16803):doi:10.1029/ 2007GL029819

217. McConnell JR, Edwards R, Kok GL, Flanner MG, Zender CS, Saltzman ES, Banta JR, Pasteris DR, Carter MM, Kahl JDW (2007) Twentieth-century industrial black carbon emissions altered arctic climate forcing. Science 317(5843):1381-1384

218. Bisiaux MM, Edwards R, McConnell JR, Albert MR, Anschütz H, Neumann TA, Isaksson E, Penner JE (2012) Variability of black carbon deposition to the east Antarctic plateau, 1800-2000 AD. Atmos Chem Phys 12(8):3799-3808. doi:10.5194/acp-12-3799-2012

219. Kaspari SD, Schwikowski M, Gysel M, Flanner MG, Kang S, Hou S, Mayewski PA (2011) Recent increase in black carbon concentrations from a Mt. Everest ice core spanning 1860-2000 AD. Geophys Res Lett 38(4):L04703. doi:10.1029/2010GL046096

220. Schwarz J, Doherty S, Li F, Ruggiero S, Tanner C, Perring A, Gao R, Fahey D (2012) Assessing single particle soot photometer and integrating sphere/integrating sandwich spectrophotometer measurement techniques for quantifying black carbon concentration in snow. Atmos Meas Tech 5(11):2581-2592

221. Schwarz J, Gao R, Perring A, Spackman J, Fahey D (2013) Black carbon aerosol size in snow. Sci Rep 3:DOI:10.1038/srep01356

222. Bisiaux MM, Edwards R, Heyvaert AC, Thomas JM, Fitzgerald B, Susfalk RB, Schladow SG, Thaw M (2011) Stormwater and fire as sources of black carbon nanoparticles to Lake Tahoe. Environ Sci Technol 45(6):2065-2071

223. Ohata S, Moteki N, Kondo Y (2011) Evaluation of a method for measurement of the concentration and size distribution of black carbon particles suspended in rainwater. Aerosol Sci Technol 45(11):1326-1336

224. Gao RS, Schwarz JP, Kelly KK, Fahey DW, Watts LA, Thompson TL, Spackman JR, Slowik JG, Cross ES, Han J-H, Davidovits P, Onasch TB, Worsnop DR (2007) A novel method for estimating light-scattering properties of soot aerosols using a modified singleparticle soot photometer. Aerosol Sci Technol 41(2):125-135

225. Moteki N, Kondo Y (2008) Method to measure time-dependent scattering cross sections of particles evaporating in a laser beam. J Aerosol Sci 39(4):348-364

226. Sedlacek AJ, Lewis ER, Kleinman L, Xu J, Zhang Q (2012) Determination of and evidence for non-core-shell structure of particles containing black carbon using the single-particle soot photometer (SP2). Geophys Res Lett 39 (L06802):doi:10.1029/ 2012GL050905

227. Schwarz JP, Spackman JR, Fahey DW, Gao RS, Lohmann U, Stier P, Watts LA, Thomson DS, Lack DA, Pfister L, Mahoney MJ, Baumgardner D, Wilson JC, Reeves JM (2008) Coatings and their enhancement of black carbon light absorption in the tropical atmosphere. J Geophys Res 113 (D03203):doi:10.1029/2007JD009042

228. Liu DY, Allan J, Whitehead J, Young D, Flynn M, Coe H, McFiggans G, Fleming ZL, Bandy B (2013) Ambient black carbon particle hygroscopic properties controlled by mixing state and 
composition. Atmos Chem Phys 13:2015-2029. doi:10.5194/acp13-2015-2013

229. McMeeking GR, Good N, Petters MD, McFiggans G, Coe H (2011) Influences on the fraction of hydrophobic and hydrophilic black carbon in the atmosphere. Atmos Chem Phys 11(10):5099-5112. doi:10.5194/acp-11-5099-2011

230. Schulz C, Kock BF, Hofmann M, Michelsen H, Will S, Bougie B, Suntz R, Smallwood G (2006) Laser-induced incandescence: recent trends and current questions. Appl Phys B 83(3):333-354

231. Vander Wal RL, Choi MY, Lee K-O (1995) The effects of rapid heating of soot: implications when using laser-induced incandescence for soot diagnostics. Combust Flame 102(1/2):200-204

232. Moteki N, Kondo Y (2007) Effects of mixing state on black carbon measurements by laser-induced incandescence. Aerosol Sci Technol 41(4):398-417

233. Gysel M, Laborde M, Olfert JS, Subramanian R, Gröhn AJ (2011) Effective density of aquadag and fullerene soot black carbon reference materials used for SP2 calibration. Atmos Meas Tech 4(12):2851-2858

234. Laborde M, Mertes P, Zieger P, Dommen J, Baltensperger U, Gysel M (2012) Sensitivity of the single particle soot photometer to different black carbon types. Atmos Meas Tech 5(5):1031-1043

235. Schwarz JP, Spackman JR, Gao RS, Perring AE, Cross E, Onasch TB, Ahern A, Wrobel W, Davidovits P, Olfert J, Dubey MK, Mazzoleni C, Fahey DW (2010) The detection efficiency of the single particle soot photometer. Aerosol Sci Technol 44(8):612-628

236. Akagi SK, Craven JS, Taylor JW, McMeeking GR, Yokelson RJ, Burling IR, Urbanski SP, Wold CE, Seinfeld JH, Coe H, Alvarado MJ, Weise DR (2012) Evolution of trace gases and particles emitted by a chaparral fire in California. Atmos Chem Phys 12(3):13971421. doi:10.5194/acp-12-1397-2012

237. Canagaratna MR, Jayne JT, Jimenez JL, Allan JD, Alfarra MR, Zhang Q, Onasch TB, Drewnick F, Coe H, Middlebrook A, Delia A, Williams LR, Trimborn AM, Northway MJ, DeCarlo PF, Kolb CE, Davidovits P, Worsnop DR (2007) Chemical and microphysical characterization of ambient aerosols with the aerodyne aerosol mass spectrometer. Mass Spectrom Rev 26(2):185-222

238. Onasch TB, Trimborn A, Fortner EC, Jayne JT, Kok GL, Williams LR, Davidovits P, Worsnop DR (2012) Soot particle aerosol mass spectrometer: development, validation, and initial application. Aerosol Sci Technol 46(7):804-817

239. Chakrabarty RK, Moosmüller H, Arnott WP, Garro MA, Walker JW (2006) Structural and fractal properties of particles emitted from spark ignition engines. Environ Sci Technol 40(21):6647-6654

240. Chakrabarty RK, Moosmüller H, Garro MA, Arnott WP, Walker JW, Susott RA, Babbitt RE, Wold CE, Lincoln EN, Hao WM (2006) Emissions from the laboratory combustion of wildland fuels: particle morphology and size. J Geophys Res 111 (D07204):doi:10. 1029/2005JD006659

241. Wentzel M, Gorzawski H, Naumann K-H, Saathoff H, Weinbruch S (2003) Transmission electron microscopical and aerosol dynamical characterization of soot aerosols. J Aerosol Sci 34(10):1347-1370

242. Pósfai M, Simonics R, Li J, Hobbs PV, Buseck PR (2003) Individual aerosol particles from biomass burning in southern Africa: 1. Compositions and size distributions of carbonaceous particles. J Geophys Res 108 (D13):DOI:10.1029/2002JD002291

243. Dhaubhadel R, Pierce F, Chakrabarti A, Sorensen CM (2006) Hybrid superaggregate morphology as a result of aggregation in a cluster-dense aerosol. Phys Rev E 73(1):011404

244. Jullien R, Botet R (1987) Aggregation and fractal aggregates. World Scientific, Singapore

245. Jullien R, Kolb M, Botet R (1984) Diffusion limited aggregation with directed and anisotropic diffusion. J Phys 45(3):395-399

246. Forrest SR, Witten TA (1979) Long-range correlations in smokeparticle aggregates. J Phys A Math Gen 12(5):L109-L117

247. Sorensen (2001) Light scattering by fractal aggregates: a review. Aerosol Sci Technol 35(2):648-687
248. Sorensen CM, Chakrabarti A (2011) The sol to gel transition in irreversible particulate systems. Soft Matter 7(6):2284-2296. doi: $10.1039 / \mathrm{C} 0 \mathrm{sm} 00228 \mathrm{c}$

249. Heinson WR, Sorensen CM, Chakrabarti A (2010) Does shape anisotropy control the fractal dimension in diffusion-limited cluster-cluster aggregation? Aerosol Sci Tech 44 (12):I-Iv

250. Sorensen CM, Cai J, Lu N (1992) Light-scattering measurements of monomer size, monomers per aggregate, and fractal dimension for soot aggregates in flames. Appl Opt 31(30):6547-6557

251. Katrinak KA, Rez P, Perkes PR, Buseck PR (1993) Fractal geometry of carbonaceous aggregates from an urban aerosol. Environ Sci Technol 27(3):539-547

252. Xiong C, Friedlander SK (2001) Morphologic properties of atmospheric aerosol aggregates. Proc Natl Acad Sci U S A 98(21): 11851-11856

253. Park K, Kittelson D, McMurry P (2004) Structural properties of diesel exhaust particles measured by transmission electron microscopy (TEM): relationships to particle mass and mobility. Aerosol Sci Technol 38(9):881-889

254. China S, Mazzoleni C, Gorkowski K, Aiken AC, Dubey MK (2013) Morphology and mixing state of individual freshly emitted wildfire carbonaceous particles. Nat Commun 4:DOI:10.1038/ ncomms 3122

255. Chakrabarty RK, Garro MA, Garro BA, Chancellor S, Moosmüller H, Herald CM (2011) Simulation of aggregates with pointcontacting monomers in the cluster-dilute regime. Part 1: determining the most reliable technique for obtaining three-dimensional fractal dimension from two-dimensional images. Aerosol Sci Technol 45(1):75-80

256. Cai J, Lu N, Sorensen CM (1993) Comparison of size and morphology of soot aggregates as determined by light-scattering and electron microscope analysis. Langmuir 9(11):2861-2867

257. Oh C, Sorensen CM (1997) The effect of overlap between monomers on the determination of fractal cluster morphology. J Colloid Interface Sci 193(1):17-25

258. Sorensen CM, Feke GD (1996) The morphology of macroscopic soot. Aerosol Sci Technol 25(3):329-337

259. Samson RJ, Mulholland GW, Gentry JW (1987) Structural analysis of soot agglomerates. Langmuir 3(2):272-281

260. Köylü ÜÖ, Faeth GM, Farias TL, Carvalho MG (1995) Fractal and projected structure properties of soot aggregates. Combust Flame 100(4):621-633

261. Brasil AM, Farias TL, Carvalho MG (1999) A recipe for image characterization of fractal-like aggregates. J Aerosol Sci 30(10): 1379-1389

262. Puri R, Richardson TF, Santoro RJ, Dobbins RA (1993) Aerosol dynamic processes of soot aggregates in a laminar ethene diffusion flame. Combust Flame 92(3):320-333

263. Megaridis CM, Dobbins RA (1990) Morphological description of flame-generated materials. Combust Sci Technol 71(1/3):95-109

264. Chakrabarty RK, Garro MA, Garro BA, Chancellor S, Moosmüller H, Herald CM (2011) Simulation of aggregates with point-contacting monomers in the cluster-dilute regime. Part 2: comparison of Two- and three-dimensional structural properties as a function of fractal dimension. Aerosol Sci Technol 45(8): 903-908

265. McDonald R, Biswas P (2004) A Methodology to establish the morphology of ambient aerosols. J Air Waste Manag Assoc 54(9): 1069-1078

266. Brasil, Farias, Carvalho (2000) Evaluation of the fractal properties of cluster-cluster aggregates. Aerosol Sci Technol 33(5): 440-454

267. Janssen NA, Gerlofs-Nijland ME, Lanki T, Salonen RO, Cassee F, Hoek G, Fischer P, Brunekreef B, Krzyzanowski M (2012) Health effects of black carbon. World Health Organization, Copenhagen 